האקדמיה הצעירה הישראלית

الأكاديمية الشابّة الإسـرائيلية

THE ISRAEL YOUNG ACADEMY

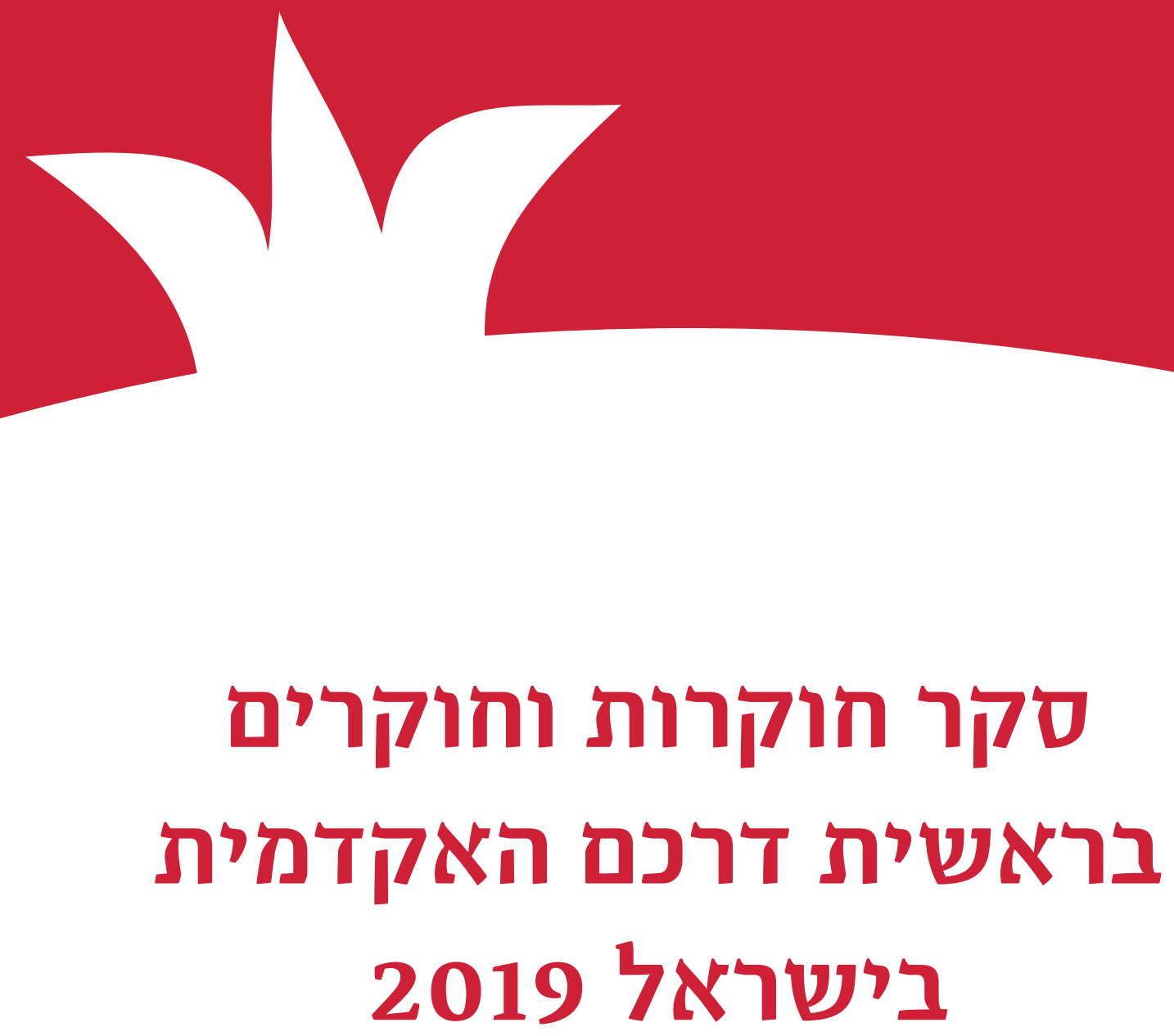

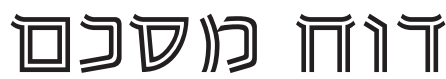




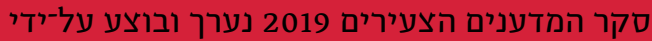

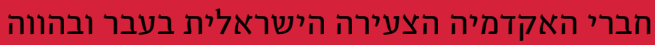

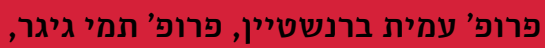

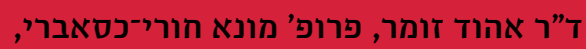

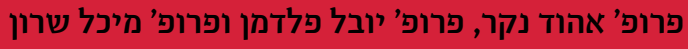

התוצאות נותחו על־ידי פרופ' עמית ברנשטיין ופרופ' אהוד נקר עוּי נופר

הדוח המסכם נכתב על-ידי

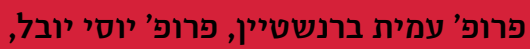

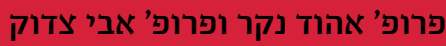

תודה מיוחדת למרב עטר, רכזת האקדמיה הצעירה הישראלית מערית

עריכת לשון: יהודית (דיתיק) ידלין עיצוב ועריכה גרפית: סטודיו נאוי קצמן־כדורי (דיורי ידוריו

( • האקדמיה הצעירה הישראלית 2021

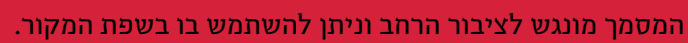

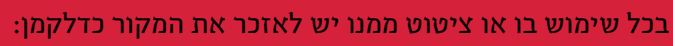

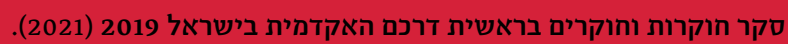
ירושלים: האקדמיה הצעירה הישראלית

https://doi.org/10.52873/Young.2021.Survey האקדמיה הצעירה הישראלית כיכר אלברט איינשטיין, ת"ד 4040, ירושלים 9104001 דואר אלקטרוני: IsraelYoungAcademy@academy.ac.il www.young.academy.ac.il 
האקדמיה הצעירה הישראלית ועצית

الأكاديمية الشابّة الإسرائيلية

THE ISRAEL YOUNG ACADEMY

\section{סקר חוקרות וחוקרים בראשית דרכם האקדמית בישראל 2019}




\section{תקקציר מנהלים}

באביב 2019 ערכה האקדמיה הצעירה הישראלית סקר מקיף, שני מסוגו, בקרב חברי הסגל הבכיר שנקלטו באוניברסיטאות המחקר בשנים 2018-2009 ובו השתתפו כאלף משיבים. הסקר נועד לספק תמונת מצב מפורטת וייחודית בנוגע לחברי וחברות סגל בתחילת דרכם באקדמיה הישראלית, לתקף את המדיניות בנושא ולזהות נקודות חוזק ונקודות הטעונות שיפור. הסקר עוסק בסוגיות רבות: השתלמות בתר־דוקטורט טרם קבלת המשרה, תהליכי קליטה, תמיכה מוסדית, גיוס תלמידי

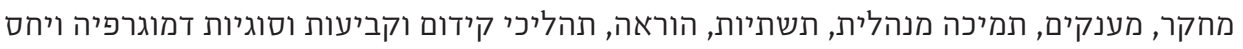
למיעוטים. להלן מובאות המסקנות העיקריות מהסקר. יש לשים לב שהסקר נעשה לפני מגפת הקורונה, ולכן השפעות המגפה אינן באות לידי ביטוי בתוצאותיו. עם זאת התמונה שעולה מהסקר עודנה רלוונטית מאוד גם היום.

מהשוואת תוצאות הסקר הנוכחי לאלה של הסקר שנערך לפני שש שנים (שסקר חוקרים שנקלטו

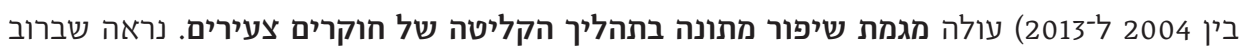

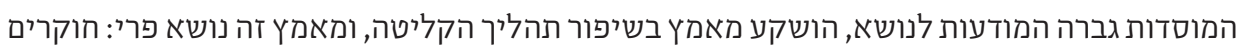

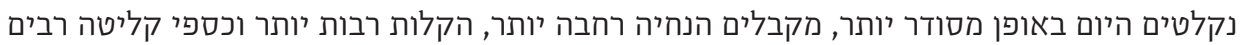
יותר. לצד זאת חברות וחברי סגל חדשים עדיין ניצבים בפני חסמים רבים, ובכללם עומס הוראה ואדמיניסטרציה בשנים הראשונות לאחר הקליטה ותמיכה מועטה של המערכת האדמיניסטרטיבית

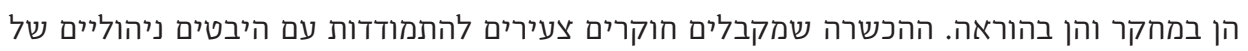
עבודתם לוקה בחסר, וחלק ניכר מן החוקרים הזקוקים למעבדת מחקר קיבלו אותה באיחור רב. נוסף על זה, הסקר מעלה כמה נושאים רוחביים בולטים הדורשים תשומת לב מיוחדת: קיים פער ניכר בין החוויה האקדמית של חוקרות וחוקרים צעירים במדעי הרוח והחברה לבין החוויה של עמיתיהם במדעים המדויקים, מדעי החיים והנדסה (STEM+LS).

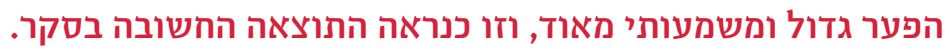
הפער בא לביטוי כמעט בכל אספקט של החיים האקדמיים, והוא גדול בהרבה מפערים שנצפו בכל חלוקה אחרת, למשל לפי מוסד או מגדר. התמונה העולה מהסקר היא כי באותם מוסדות קיימות 
למעשה שתי תרבויות אקדמיות שונות מאוד זו מזו. בהשוואה לחבריהם במדעי הרוח והחברה, בחוקרים ובחוקרות ממדעי ה־STEM+LS מושקעים משאבים רבים יותר, הם זוכים לתשתיות

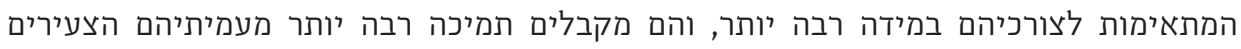

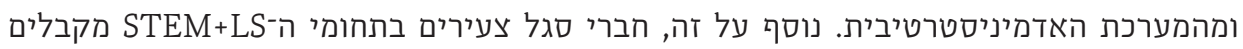

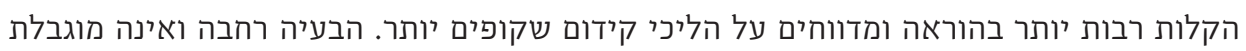

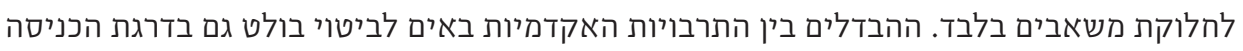
לסגל האקדמי הבכיר: כ־50\% מהחוקרים המשיבים במדעי הרוח והחברה התקבלו בדרגת מרצה אף שהשתלמו בבתר־דוקטורט, לעומת כ־10\% בלבד במדעי הטבע והחיים ובהנדסה.

רוב גדול של החוקרים הצעירים מאוכזב ומתוסכל מהאופן שבו מתנהלים הליכי הקביעות

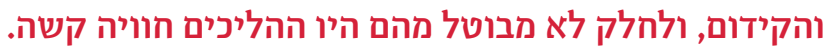

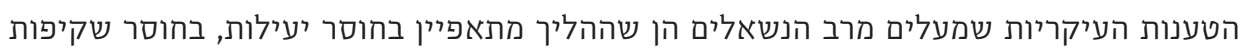

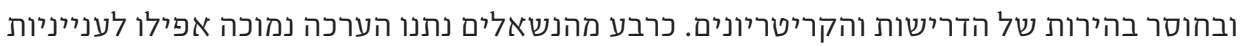
ההליך ולמקצועיותו. תוצאה זו חוצה מוסדות ותחומי דעת. הליכי הקידום וקבלת הקביעות

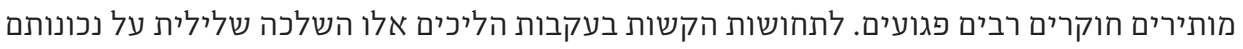

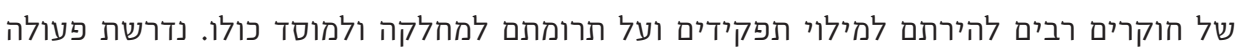

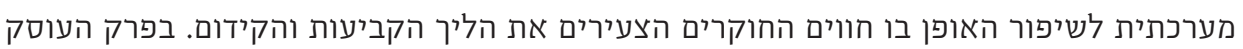
בנושא אנו מציעים כמה דרכי פעולה אפשריות, אשר אינן דורשות השקעת משאבים גדולה, ושלהערכתנו יכולות להביא לשיפור ניכר בנושא.

הפער בייצוג המגדרי במקצועות ה־STEM+LS גדול בהרבה מזה שבמדעי הרוח והחברה.

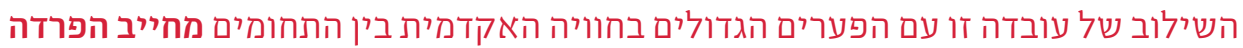
דיסציפלינרית בניתוח מגדרי של הנתונים על מנת שפערים שמקורם דיסציפלינרי לא יפורשו בטעות כפערים מגדריים. מבחינה של הנתונים בחלוקה דיסציפלינרית, אף שהסקר לא תוכנן באופן אופטימלי לבחינת כופרים מהפרים

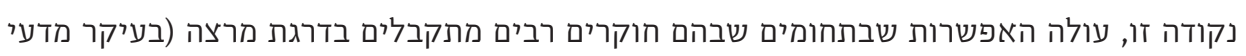

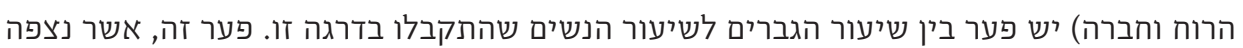
רק בחלק מהמוסדות ובחלק מהדיסציפלינות, אינו מוסבר על ידי הבדלים מגדריים באוכלוסיית החוקרים שיצאה להשתלמות בתר־דוקטורט. לכן אנו קוראים למוסדות השונים, אשר מחזיקים בנתונים המלאים, לבדוק את דרגת הכניסה של חברי הסגל הבכיר בחלוקה מגדרית.

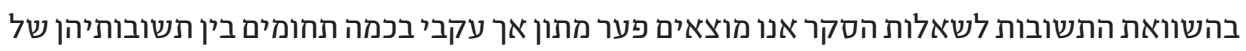
חוקרות במדעי החברה והרוח לבין עמיתיהן הגברים. הפער בא לידי ביטוי בתמיכת עמיתים ותיקים וצעירים, ביחס המערכת האדמיניסטרטיבית אליהן ובתמיכה כספית. במקצועות ה־STEM+LS כמעט שלא נמצא פער בין נשים לגברים בתשובות לשאלות השונות. 


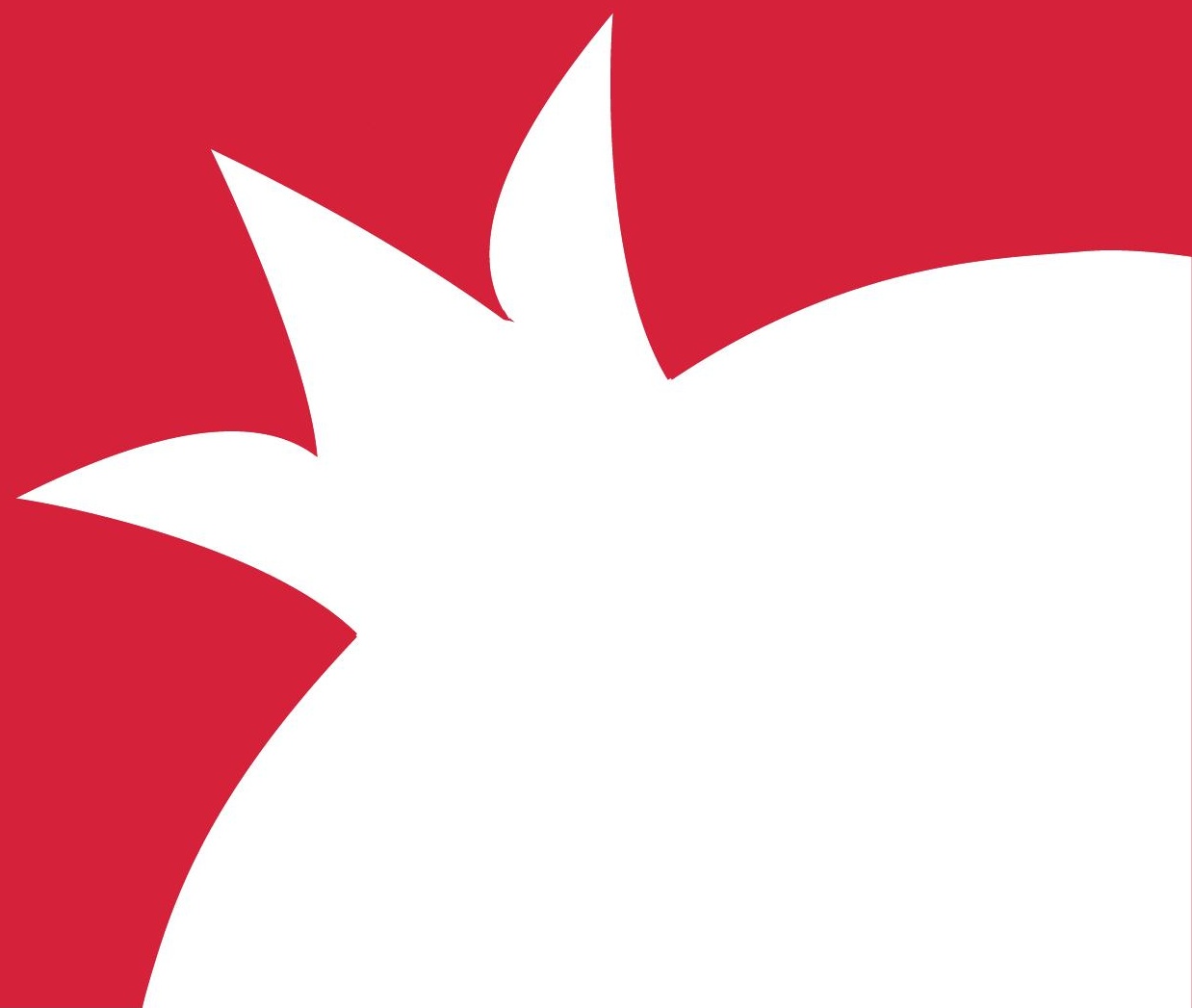




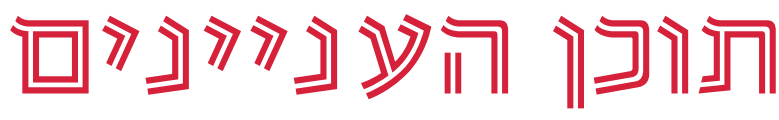

34

מגדר - - - - - - - - - - - - 



\section{(0) 1 מבנה הסקר ואוכלוסיית המדגם}

אוכלוסיית היעד של הסקר היא כל החוקרים והחוקרות שהתקבלו במסלול רגיל לקביעות בעשר

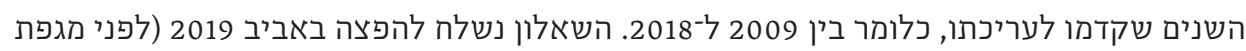
הקורונה) לכל אוניברסיטאות המחקר בארץ ולמכון ויצמן למדע, וכל אחד מהמוסדות האלה הפיץ את הסקר בקרב חבריו המתאימים.'

השאלון מנה כ־50 שאלות הנוגעות במגוון רחב של היבטים מהחיים האקדמיים. את השאלון המלא,

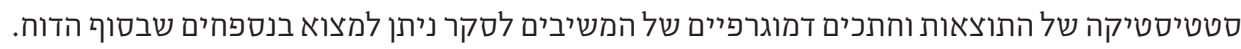
ברוב השאלות נתבקשו המשיבים לדרג את התשובה בסולם של 0 עד 10 כאשר ניסוחן של חלק מהשאלות היה חיובי (למשל "עד כמה תמכו בך חוקרים צעירים אחרים?") ושל חלק אחר - שלילי

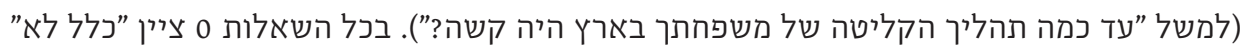

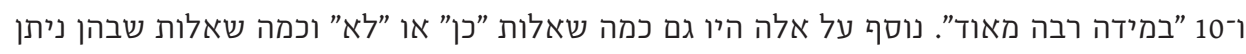
מקום להוספת טקסט חופשי.

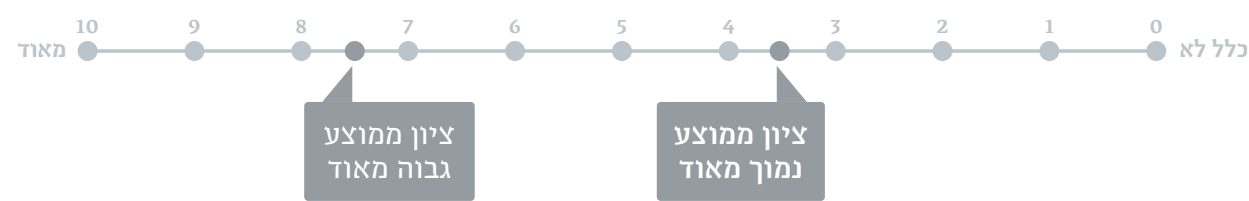

בסיכום המוצג במסמך זה יש התייחסות ברבים מהנושאים לממוצע התשובות של שאלה כזו או אחרת. ככלל, הממוצע והחציון של התשובות למרבית השאלות נעו בין 3 ל־8, כאשר ציונים נמוכים

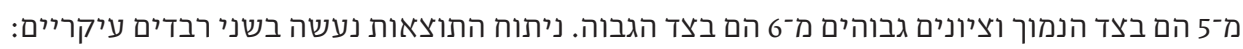
(1) על פני כלל אוכלוסיית המשיבים; (2) על פי חלוקה למוסדות.

מטרת מסמך זה היא לסכם את התשובות של כלל אוכלוסיית המשתתפים ואת המסקנות העיקריות העולות מתשובות אלו. תוצאות הסקר בכל מוסד יוצגו בנפרד, לפני הנהלת המוסד בלבד.
אוכלוסיית

המדגם

מבנה הסקר

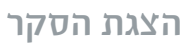




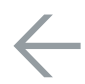

1

ניתן לראות כמה בתום

מהמאפיינים הדמוגרפיים

של המשיבים לסקר.

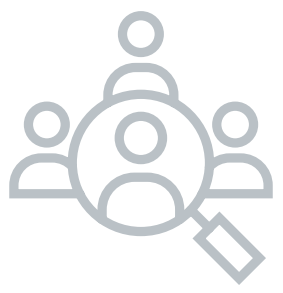

החוקרים שהשיבו לסקר הם

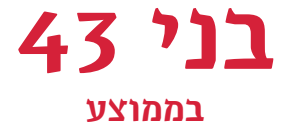

* רובם נשואים עם ילדים נובדים

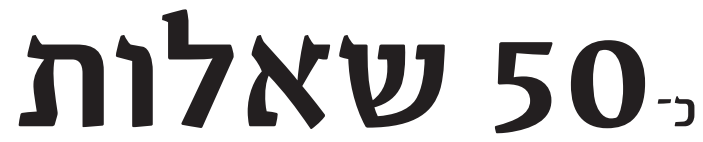

הנוגעות במגוון רחב של היבטים מהחיים האקדמיים
מן הנתונים הדמוגרפיים המלאים (נספח 2) עולה:

לסקר השיבו 936

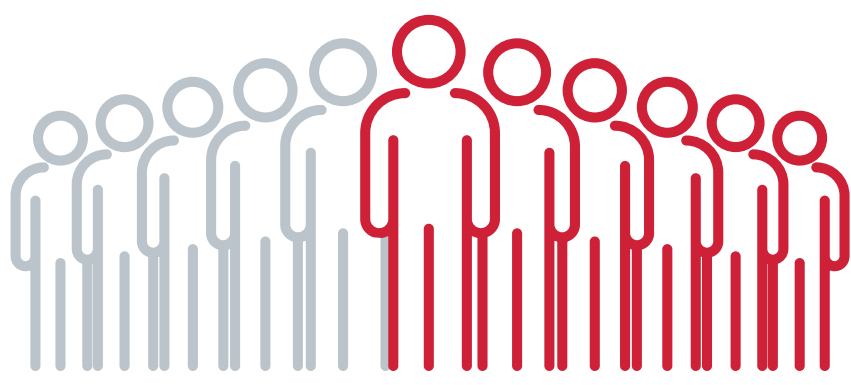

המשיבים שהזדהו מגדרית הם:

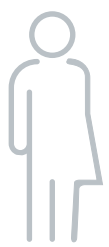

לא הזדהו

99

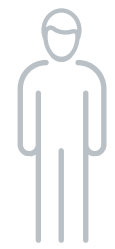

גברים

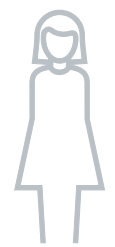

נשים

שהם כ־0\% 50 מכלל הנשאלים 
תרשים 1. מאפיינים דמוגרפיים של אוכלוסיית המדגם סה"כ החוקרים מתייחס למספר המשיבים לאותה שאלה
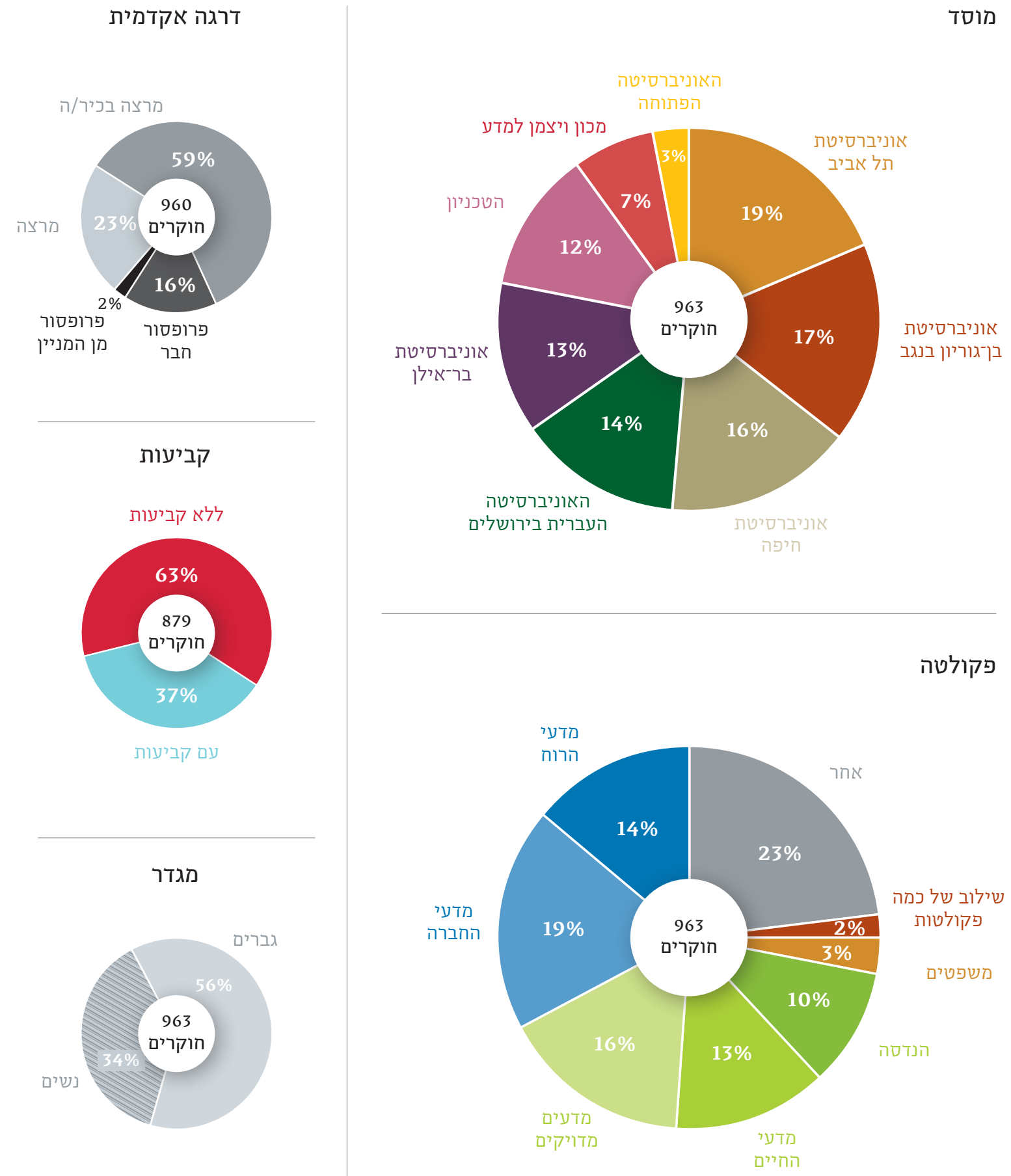


\section{(1) $\mathbb{Z}$ \\ אוניברסיטה אחת - שתי אקדמיות}

הממצא הבולט ביותר העולה מהסקר הוא פער גדול בין החוויה האקדמית של חוקרות וחוקרים

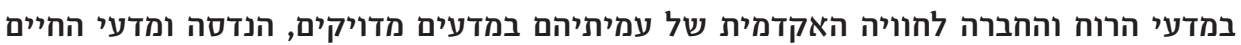

.(STEM+LS)

הפער בא לידי ביטוי ברוב הנושאים שעליהם שאלנו בסקר, והוא גדול בהרבה מפערים שנצפו בכל חלוקה אחרת, למשל לפי מוסד או מגדר. למעשה התחושה שעולה מהסקר היא שאומנם

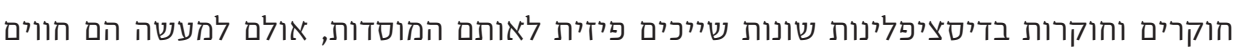
שתי אקדמיות שונות.

הפער מתחיל כבר בדרגת הכניסה לאוניברסיטה, נושא שאנו דנים בו בהרחבה בפרק המוקדש לזה. נוסף על זה, בנושאים רבים הציונים שנותנים חוקרי STEM+LS עולים במובהק על אלו שנותנים חוקרים במדעי הרוח והחברה. להלן דוגמאות מאוגדות לפי נושאים (רשימת השאלות שבהן נצפה

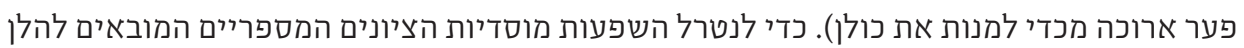
משווים את מדעי הרוח והחברה למדעים מדויקים, למדעי החיים ולהנדסה כאשר מצרפים את כל החוקרים במוסדות שבהם יש מספר גדול של חוקרות וחוקרים מכל הדיסציפלינות (כלומר ללא הטכניון ומכון ויצמן למדע).

מספר רב של שאלות מעיד שהמשאבים המושקעים בחוקרים וחוקרות במדעי ה־STEM+LS רבים יותר גם כשמביאים בחשבון את הצרכים השונים של כל אחת מהקבוצות: חלק גדול יותר מהחוקרים והחוקרות במדעי ה־STEM+LS מקבל מענקי קליטה (94\% לעומת 72\% במדעי הרוח והחברה), מבלי להתייחס כלל לסכום המענק; המענקים שהם מקבלים מקרנות המחקר מספיקים יותר למימון מלגות ומשכורות (ציון ממוצע של 7.1 ב־STEM+LS; ציון ממוצע 6.2 במדעי הרוח והחברה); המשרדים שהם מקבלים מתאימים יותר לצורכיהם (7.4 / 7.4); האוניברסיטה מספקת להם תשתיות מחקר רבות יותר,

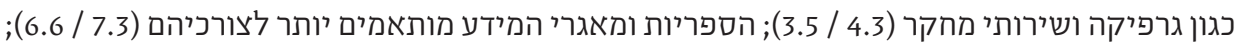
ההקלות בהוראה שהם מקבלים בשנתם הראשונה רבות יותר בהרבה (7.1 / 4.7) ועוד. 
יש הבדל ניכר גם במגוון רחב של נושאים שאינם דורשים השקעה כספית גדולה, כמו תמיכה.

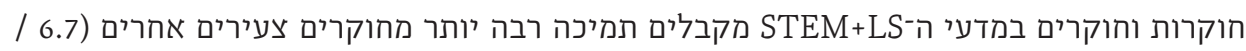

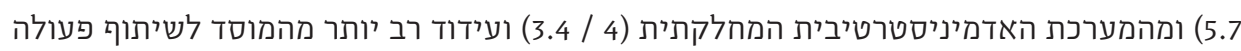

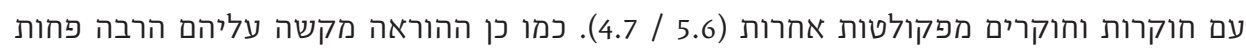

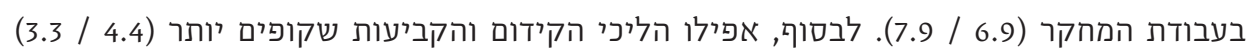
והקריטריונים והדרישות בהירים יותר (5.1 / (4.1). הסקר מעלה תמונה לא פשוטה של הפערים הקיימים בתוך האוניברסיטאות ומדגיש את הצורך

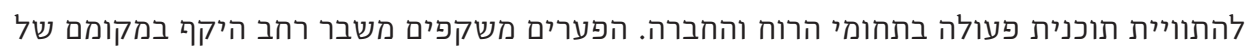

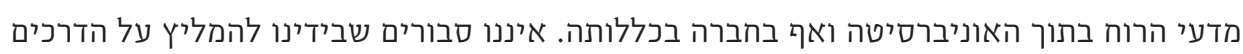

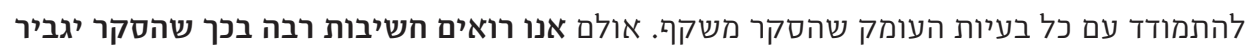
את המודעות לפערים אלו ויספק עדויות לרוחבה של הבעיה ולאופן שבו משתקפים הקשיים שאותם חווים חוקרות וחוקרים במדעי הרוח והחברה כמעט בכל היבט של החיים האקדמיים. יתרה מזאת, הבעיה אינה מוגבלת לחלוקת משאבים בלבד. נראה שלצד התאמתם של חוגים ומחלקות במדעי הרוח והחברה לשינויים רחבים הבאים לידי

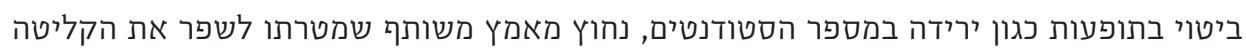
ואת החוויה האקדמית של חוקרים וחוקרות במדעי הרוח והחברה. מאמץ זה מתחייב, ולו מכיוון

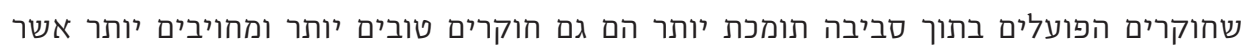
תורמים יותר למוסד שבו הם חוקרים ולאקדמיה בכלל. נתון מעודד ומעניין מהסקר הוא שהמצב אינו זהה בכל המוסדות, ואפילו יש מחלקות במדעי

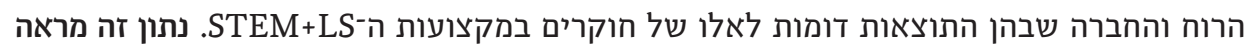
שבהתנהלות נכונה ניתן להביא לשיפור ניכר. 
תרשים 2. השוואה בין מדעי החיים, מדעים מדויקים והנדסה למדעי הרוח והחברה

השגיאות המסומנות כאן ובתרשימים הבאים הן שגיאות התקן של הממוצע (SEM)

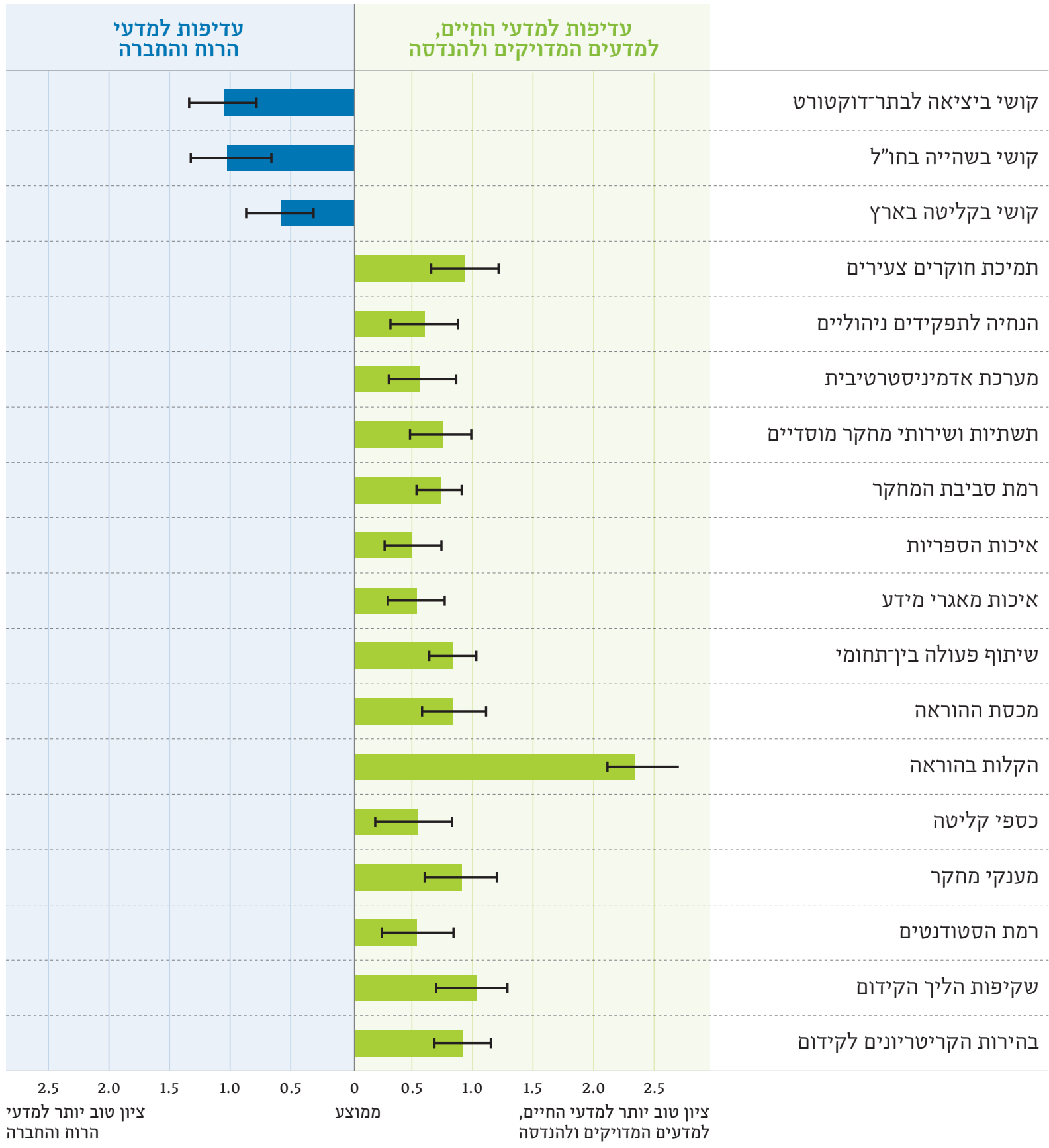




\section{3 \\ קביעות וקידום}

הליכי הקביעות והקידום הם מן הנושאים המטרידים ביותר את הסגל הצעיר.

מהסקר עולה כי רבים מחברי הסגל אשר עברו את הליכי הקביעות או הקידום בהצלחה נותרו עם

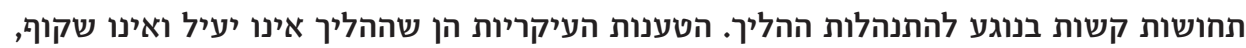
ושהדרישות והקריטריונים אינם ברורים.

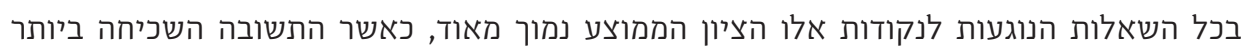

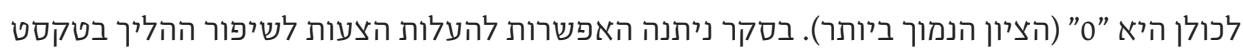
חופשי. שיעור נשאלים רב מאוד ביחס לנהוג בשאלונים כאלו (60\%, יותר מבכל נושא אחר) התייחס

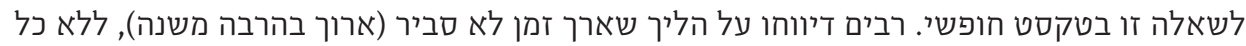

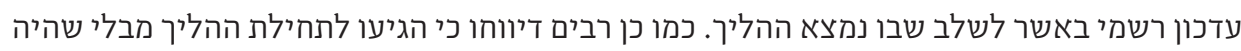

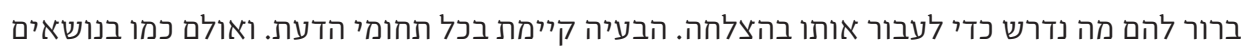

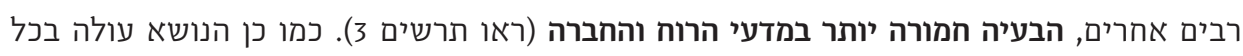

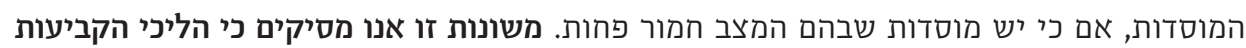
והקידום ניתנים לשיפור, בוודאי באותם מוסדות שבהם המצב חמור יחסית.

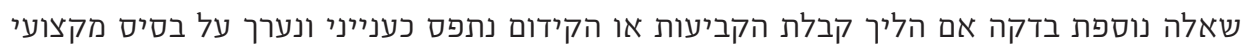

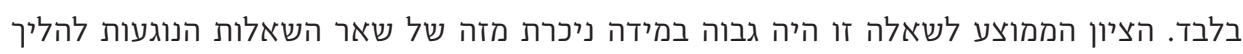

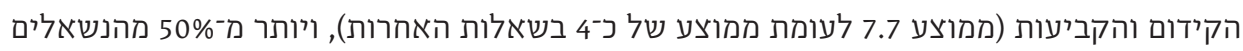
נתנו לשאלה זו ציון 9 או 10. אולם גם בנושא קריטי זה מספר לא זניח של משיבים מתאר את ההליך כלא ענייני: כ־20\% מהנשאלים נתנו לשאלה זו ציון 5 או נמוך יותר.

לבסוף נדגיש שהליכי הקביעות והקידום מלווים בתחושות קשות של מתח וחרדה ולעיתים גם של מסל מהרי

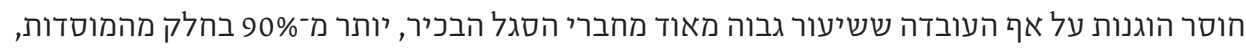
זוכה לקבל קביעות בסופו של דבר. 
הליך קבלת הקביעות הוא מרכזי וחשוב ביותר בחייהם המקצועיים של חברי הסגל הצעירים. ההליך מטיל צל כבד, והוא נוכח כמעט בכל היבט של השתלבותם של חברי וחברות סגל צעירים באקדמיה.

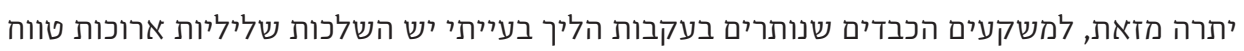

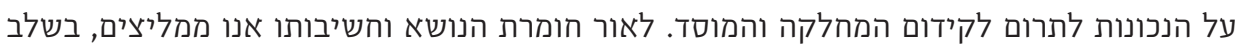

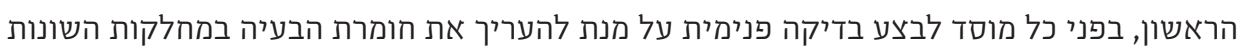
ואת השלכותיה הרחבות. בשלב השני, אנו ממליצים למוסדות להשקיע בלימוד האופן בו מתמודדים עם בעיות דומות בעולם וליישם תוכנית שמטרתה שיפור השקיפות והיעילות והבטחת ענייניותו

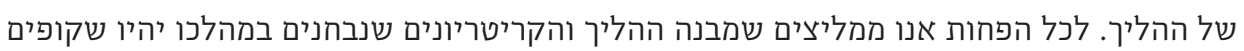

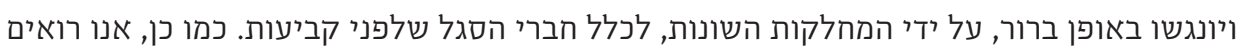
חשיבות בכך שהמועמדים שעוברים את ההליך ידעו באיזה שלב הם נמצאים. לבסוף אנו מאמינים

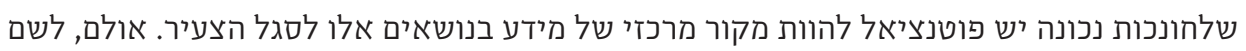
כך יש להקפיד על בחירה נכונה והדרכה של החונכים.

תרשים 3. ממוצעי התשובות לשאלות הנוגעות להליכי הקידום והקביעות

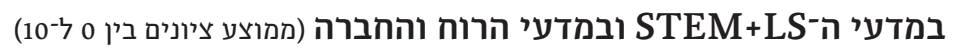
מאוד 10

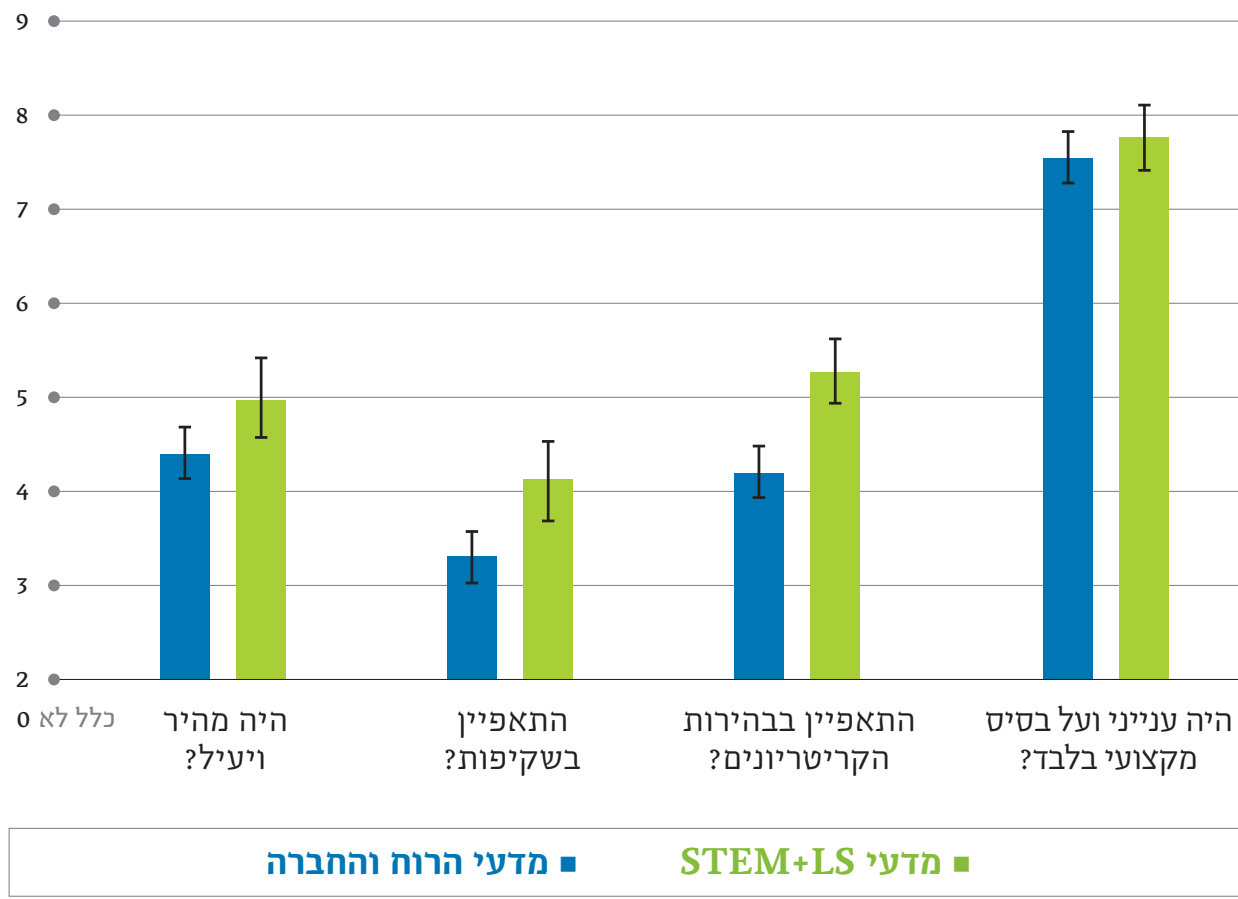

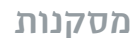

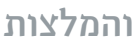

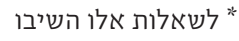
רק חוקרות וחוקרים העיבו שעברו את אחד ההליכים או את שניהם 


\section{() 44 \\ פערים בדרגת הקבלה}

הרוב המוחלט של החוקרים והחוקרות הצעירים מתחילים את המסלול לקביעות בדרגת מרצה או מרצה בכיר/ה. לדרגת הקבלה יש השפעה ארוכת טווח מאחר שבדרך כלל עוברות כמה שנים

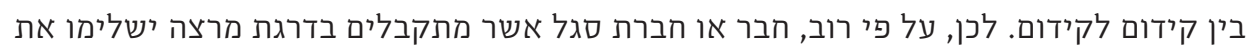

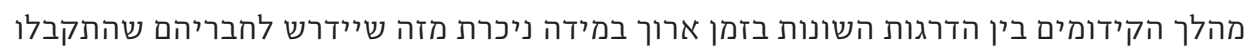
בדרגת מרצה בכיר/ה. מאחר שנוסף על ההיבט הכספי, לדרגה יש חשיבות מבחינת מעמד,

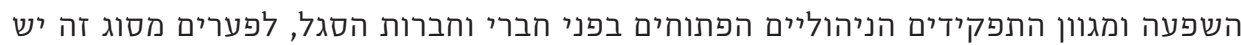
השפעה רחבה. למעשה, לדרגת הכניסה עשויה להיות, במידה רבה, השפעה על מהלך הקריירה

האקדמית כולה.

הדרגה של איש הסגל אמורה לשקף את ניסיונו ואת מעמדו האקדמי. לעיתים יש הבדלים ניכרים

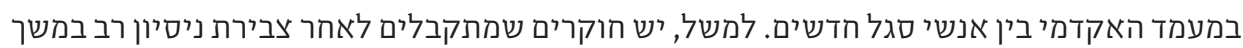
מספר שנים לא קטן של השתלמות בתר־דוקטורט, ולעומתם יש כאלו שמתקבלים לאחר השתלמות

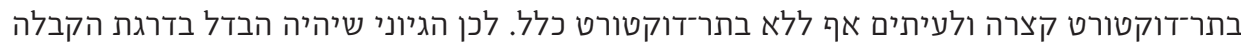

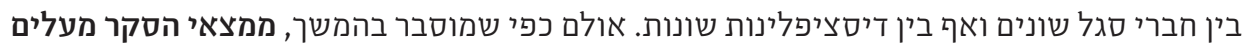
חשש שההבדל בדרגת הקבלה לא תמיד משקף פער הולם בניסיון ובמעמד האקדמי, כאשר נקודת הכשל האפשרית היא חוסר אחידות בין היחידות השונות, ולעיתים גם בתוך היחידות עצמן, בדרישות האקדמיות שבהן צריכים לעמוד חברי סגל חדשים על מנת להתקבל בדרגת מרצה בכיר במקום בדרגת מרצה. אם אכן זה המצב, הרי שיש לשנותו.

למשל, שאלנו את משתתפי הסקר לדרגתם ביום מילוי השאלון אך לא לדרגת הקבלה שלהם. לכן

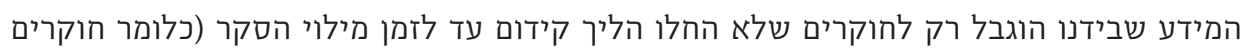

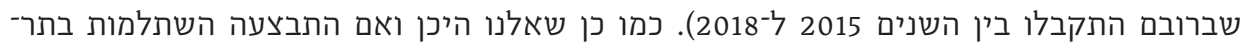
דוקטורט אך לא מה היה אורכה. יתרה מזאת, ייתכן שיש הטיות שבעטיין דרגות הכניסה של
הערת אזהרה: הסקר לא תוכנן לבחון את הפערים בדרגת הקבלה הפרים 
המשיבים לסקר אינן מייצגות את כלל אוכלוסיית היעד. על מנת לתקף את הנתונים שבידינו, ולו חלקית, ערכנו השוואה לנתוני מל"ג על דרגת הקבלה בשש השנים האחרונות. מהשוואה זו עולה

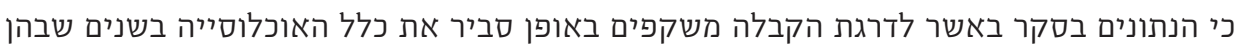

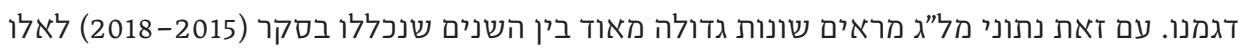

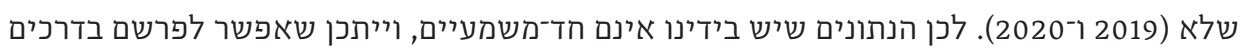
שונות. אף על פי כן נתונים אלו מעלים חשש גדול שהפערים בדרגת הקבלה אינם נובעים מסיבות

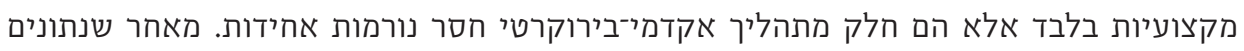

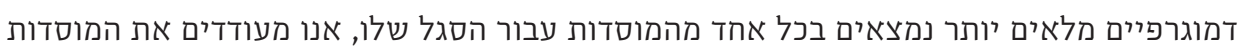
לבחון את הנתונים שבידיהם.

ידוע שיש הבדל בין הדרגות של חברי סגל חדשים בפקולטות למדעי הרוח והחברה לדרגות של חברי

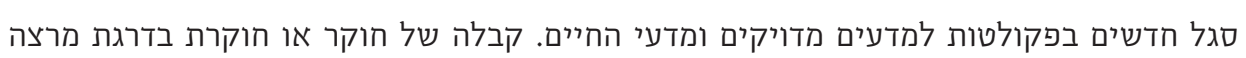
היא אירוע נדיר במדעי הטבע, ואילו במדעי הרוח והחברה רבים מהחוקרות והחוקרים המתקבלים מתחילים בדרגת מרצה. בסקר שלנו 65\% מהמשיבים ממדעי הרוח והחברה שעדיין לא עברו הליך

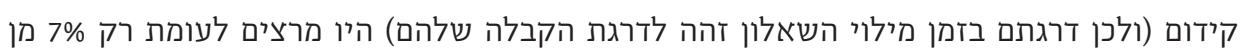
המשיבים ממדעי החיים וממדעים מדויקים. על מנת לבדוק אם הבדל זה משקף פער מקצועי בדקנו את הקשר בין דרגת הקבלה להשתלמות

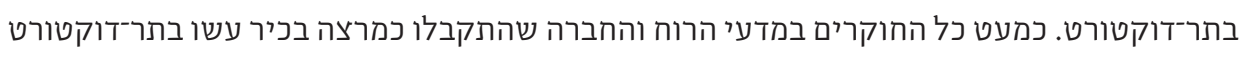

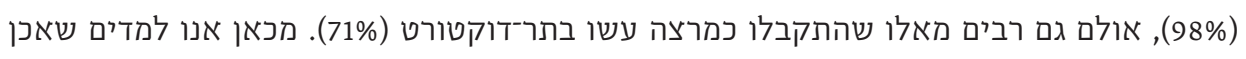
יש קשר בין השתלמות בתר־דוקטורט לדרגת הקבלה. אולם שיעורם הגבוה של החוקרים שהתקבלו כמרצה אף שעשו בתר־דוקטורט מעלה את החשש שזהו לא המקור היחיד להבדל.

במדעים המדויקים ובמדעי החיים כמעט כולם מתחילים בדרגה של מרצה בכיר, נשים וגברים

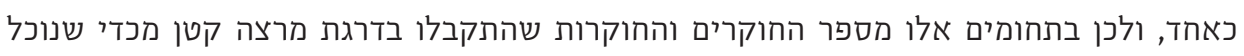

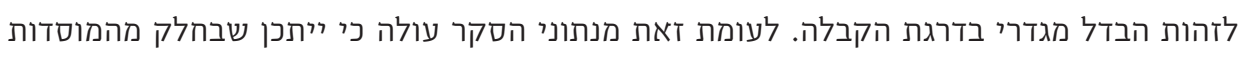

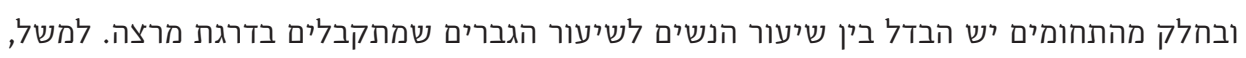
77\% מהנשים ממדעי הרוח שהשיבו לסקר לפני שקודמו היו בדרגת מרצה לעומת 52\% מהגבררים.

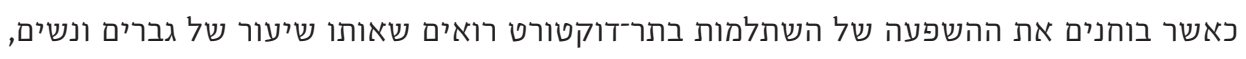
כ־20\%, לא ביצעו השתלמות בתר־דוקטורט וכולם התקבלו בדרגת מרצה. לכן, כאשר מתחשבים

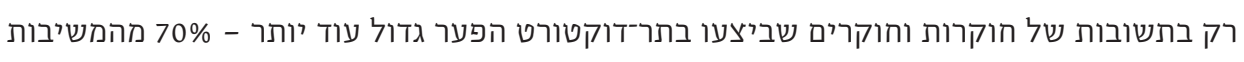
במדעי הרוח והחברה התקבלו בדרגת מרצה לאחר בתר־דוקטורט לעומת 38\% מהגברים. חשוב לנו להדגיש, שלא בכל המוסדות נצפו פערים מגדריים בדרגת הקבלה, ושגם במוסדות שבהם נצפים

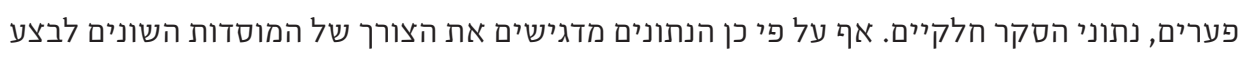
בדיקה פנימית של דרגות הקבלה בחלוקה מגדרית.

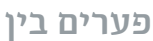
תחומי הדעת פערים

פערים מגדריים - - פ פ 
מסיכום הנתונים של הסקר עולה החשש שחסר סטנדרט אחיד לכלל המתקבלים לאוניברסיטה באשר לדרישות האקדמיות לקבלת דרגה של מרצה בכיר. התוצאה היא פערים ניכרים בין תחומי דעת שונים וייתכן שבתחומים שונים גם בין גברים ולנשים. מטבע הדברים, לא יכול להיות סטנדרט אחד שיתאים

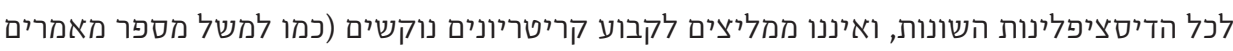
וכד') הדרושים לקבלת דרגה. עם זאת נדרשת פעולה להגברת המודעות ואולי אף לשינוי חלקים מתהליכי הקבלה והקידום על מנת שהפערים בדרגת הקבלה ישקפו אך ורק הבדלים במעמד האקדמי.

בהקשר זה חשוב להדגיש שאחד הפערים המגדריים הידועים והמדוברים ביותר הוא הירידה בשיעור

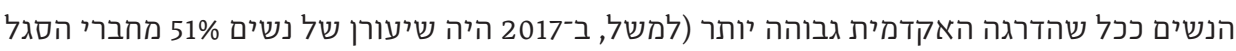

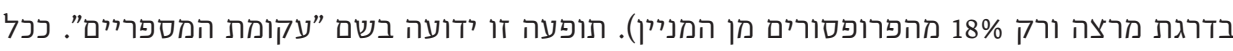

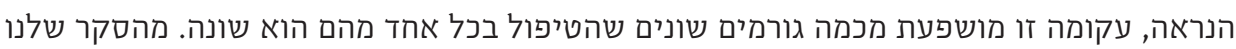
עולים שני גורמים אפשריים, אשר בדרך כלל אינם נכללים בדיון בנושא: הראשון הוא שילוב בין

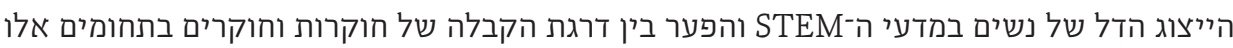

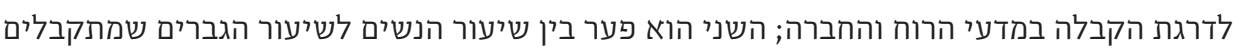
בדרגת מרצה בכיר בחלק מתחומי הדעת.

תרשים 4. החלוקה לדרגות אקדמיות של המשיבים לסקר לפי דיסציפלינה

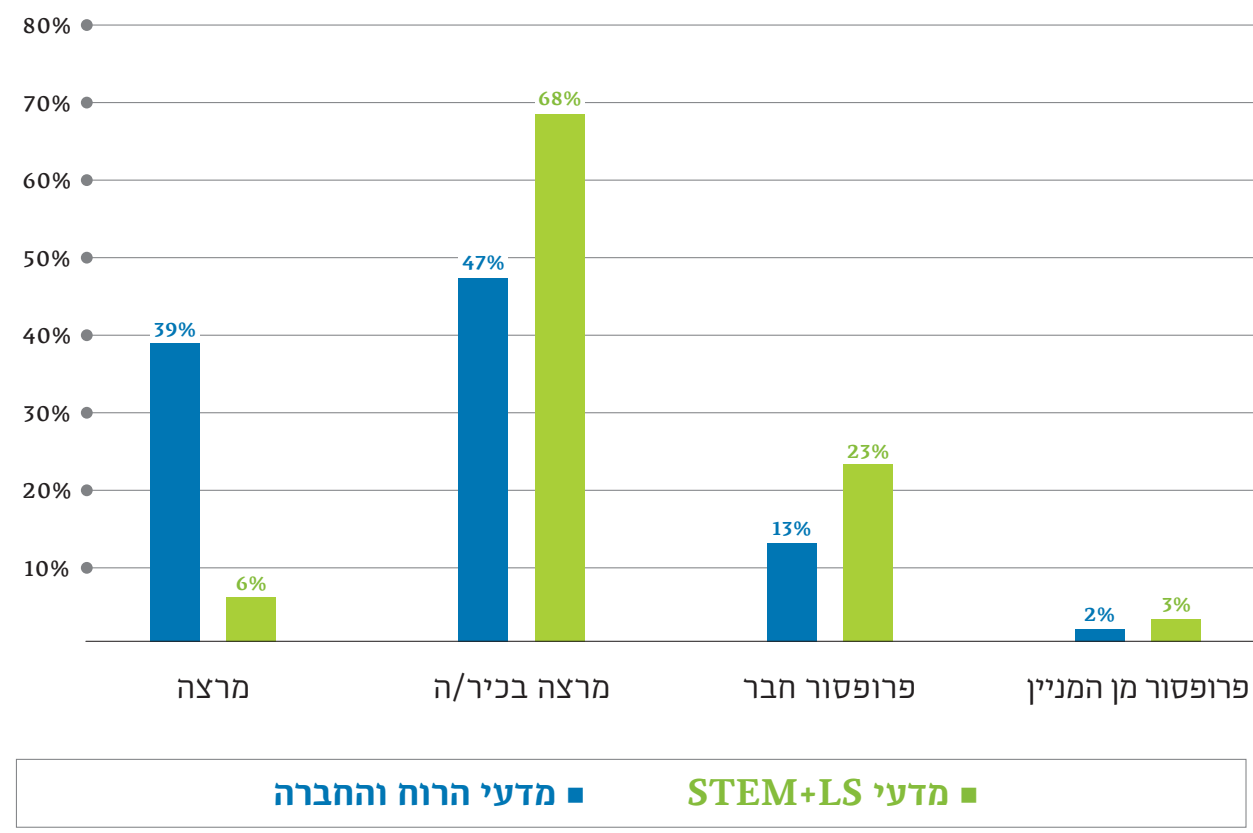




\section{שהייה בחו"ל וחזרה לארץ}

כמעט כל חברי הסגל הבכיר באוניברסיטאות בארץ נדרשים לעבור שלב הכשרה ארוך בחו"ל. הרוב עושים זאת במסגרת השתלמות בתר־דוקטורט, וחלק עושים זאת בלימודי הדוקטורט. 78\% מהמשיבים לסקר השתלמו בבתר־דוקטורט בחו"ל, 12\% השתלמו השתלמות דומה בארץ ו־10\% לא השתלמו בבתר־דוקטורט כלל (מרביתם ממדעי הרוח והחברה). מחצית מן החוקרים שלא

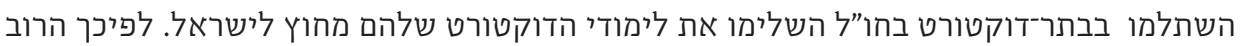

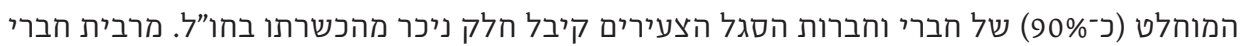
הסגל שלא עברו הכשרה בחו"ל הם ממדעי הרוח והחברה: 27\% מכלל המשיבים ממדעי הרוח ו־11\% מהמשיבים ממדעי החברה קיבלו את כל הכשרתם בארץ.

השאלון כלל שלוש שאלות שמטרתן ללמוד אם היו קשיים מיוחדים במהלך השהייה בחו"ל ובקליטה בחזרה בארץ (ראו את הציון הממוצע לכל אחת מהשאלות בתרשים 5). מטבע המדגם, שאלות אלו הופנו רק לחוקרים שהשלימו את השהייה בחו"ל בהצלחה וקיבלו משרה בארץ, ולכן המדגם אינו משקף את כלל החוקרים השוהים בחו"ל לצורך דוקטורט או בתר־דוקטורט.

ככלל, השהייה בחו"ל נתפסת כחוויה חיובית. כ־70\% מהמשיבים דיווחו שהדרישה לצבור ניסיון בחו"ל

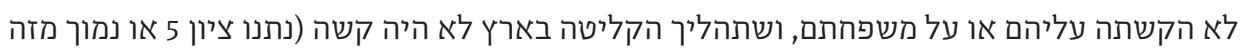

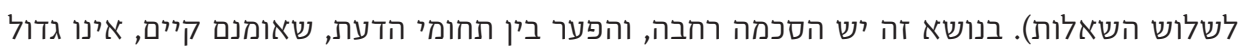
(ראו תרשים 12). יש קבוצה קטנה אך לא זניחה - כ־20\% מהחוקרות ו־15\% מהחוקרים - שדיווחה שהדרישה לצבור ניסיון בחו"ל הקשתה עליה מאוד (ציון 8 ומעלה). כמו כן כ־15\% מהחוקרות והחוקרים

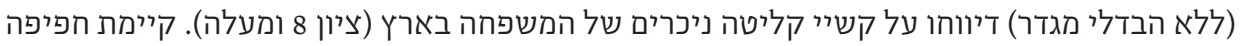

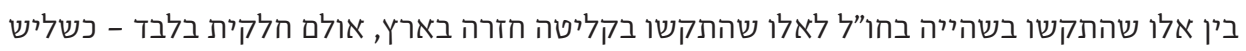

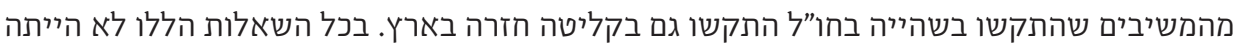
שונות גדולה בין תחומי הדעת השונים או בין המוסדות. נתון מעודד נוסף הוא ש־70\% מכלל המשיבים מצאו משרה במוסד אשר היה בעדיפות הראשונה שלהם. 
לצד התשובות החיוביות ברובן, נראה שכיום רוב המוסדות כמעט שאינם מסייעים לתהליך הקליטה בארץ של משפחות החוקרות והחוקרים אשר שבות ארצה. אנו חושבים שיש לשפר נקודה זו, אף על פי שנראה שזו בעיה שמעסיקה רק חלק קטן מהשבים ארצה. אנו מעריכים שניתן לעשות זאת

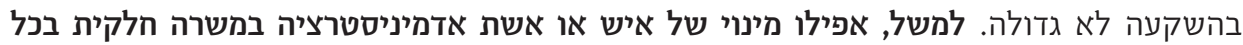

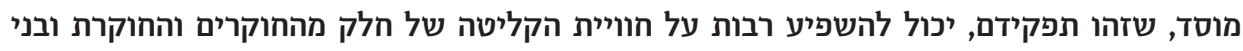
משפחותיהם. ניתן לשלב תפקיד זה עם תפקיד דומה הנדרש לקליטת סטודנטים ובתר־דוקטורנטים זרים ולטיפול בהם. חשוב להדגיש, במיוחד בנושא זה, שיש לצפות שמגפת הקורונה (שפרצה לאחר קיום הסקר) תשפיע על האתגרים שעומדים בפני חוקרים אשר מעוניינים לצאת ללימודים ולמחקר בחו"ל.

תרשים 5. ממוצאי השאלות הנוגעות לשהייה בחו"ל וחזרה לארץ (ממוצע ציונים בין 0 ל־10)

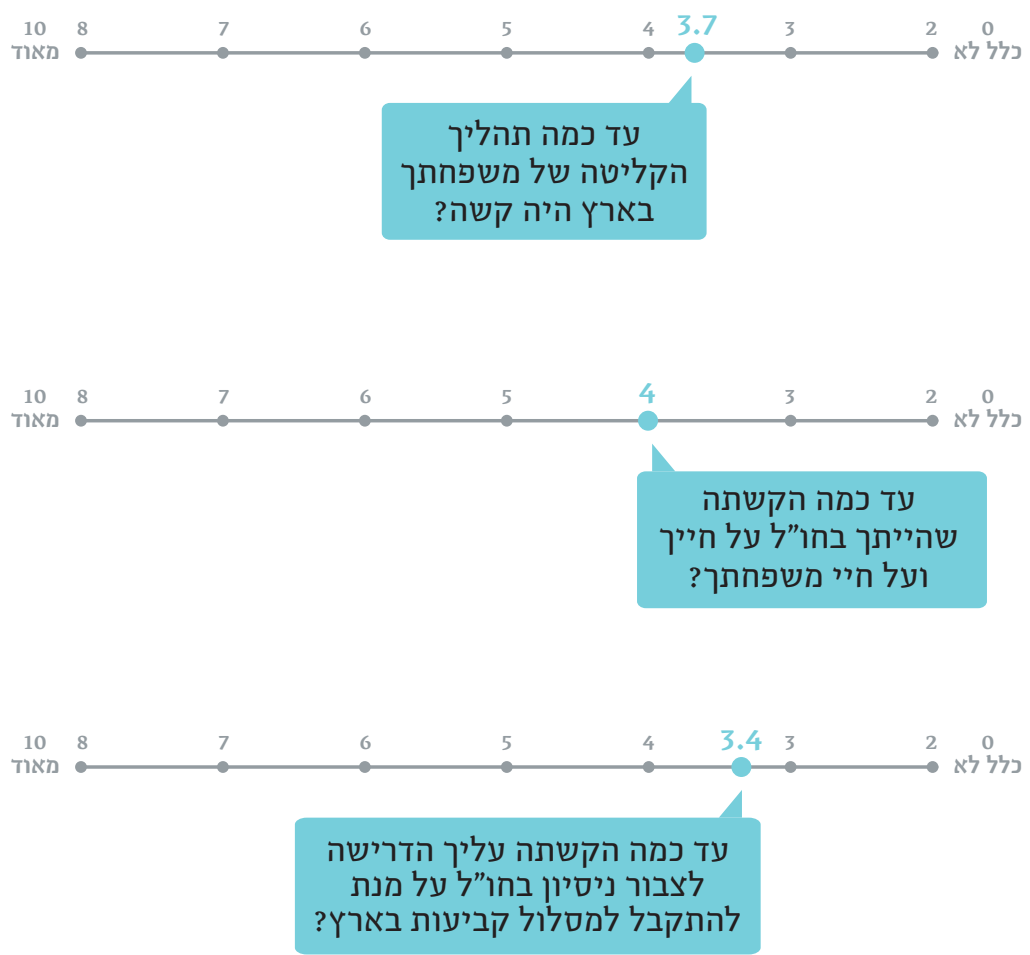

האם התקבלת למוסד שרצית בעדיפות

הראשונה?

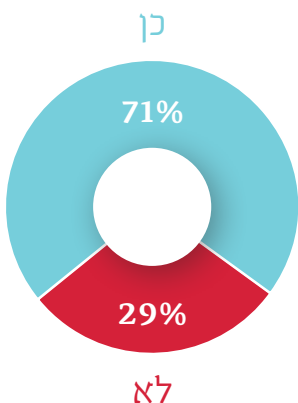

לא 
להדרכה, לסיוע ולתמיכה, הפורמלית והלא פורמלית, שמקבלים חברי סגל חדשים יש תפקיד מרכזי בקליטתם המוצלחת. אחת המסקנות העיקריות שעלו מהסקר הקודם, שנערך בסוף 2014, הייתה שבמרבית המוסדות חסר תהליך קליטה מסודר וממוסד שמכין את הנקלטים למגוון האתגרים העומדים בפניהם, מתפקידי ניהול דרך הוראה והשגת מימון מקרנות מחקר, ועד להתמודדות עם המערכת האדמיניסטרטיבית. משיחות עם הנהלת המוסדות בעקבות הסקר הקודם עלה כי מוסדות רבים מבינים את חשיבותו של הליך קליטה מסודר, ומאמץ רב מושקע בעיח בנושא.

נקודה שהעלו רבים הייתה מינוי של חונך פורמלי מקרב אנשי הסגל הוותיקים לנקלטים החדשים. בסקר הנוכחי שאלנו בעניין זה, ו־58\% מהמשיבים דיווחו שהיה להם חונך מסודר. לפי התשובות יש פער ניכר בין המוסדות השונים במספר חברי הסגל החדשים שזוכים לחונך, כאשר לצד מוסדות

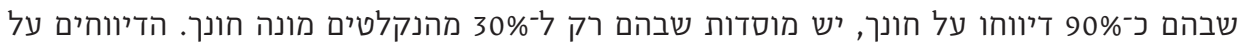

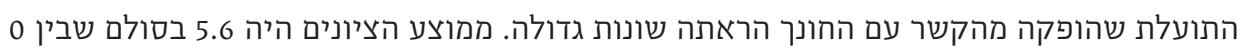
(ללא תועלת כלל) ל־10 (תועלת רבה מאוד), אך התפלגות הציונים הייתה כמעט אחידה. גם הממוצע וגם ההתפלגות היו דומים בין כל המוסדות. המסקנה היא, ככל הנראה, שאיכות החניכה תלויה

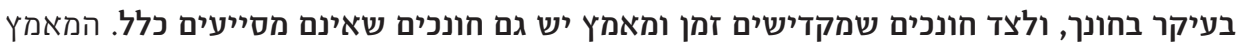
שהושקע בנושא ניכר בבחינת השינוי עם הזמן, ורואים בבירור שיפור גם במספר החונכים וגם בשביעות הרצון מתפקודם (ראו תרשים 6).

נושא נוסף שבו נצפית מגמת שיפור בסקר הנוכחי הוא הנחיה ועזרה בפנייה למענקים (ראו תרשים 13). הציון הממוצע עלה ל־6 (בינוני-גבוה) לעומת 5.1 לשאלה זהה שנשאלה בסקר הקודם. מרבית הנשאלים (כ־70\%) דיווחו שקיבלו את ההנחיה מחברי סגל ותיקים במחלקה ומרשות המחקר. מקורות משמעותיים נוספים של מידע על מענקים היו עמיתים מאוניברסיטאות אחרות והחונך.

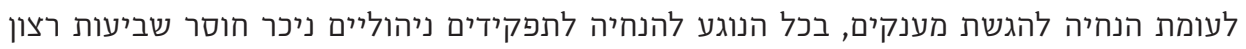

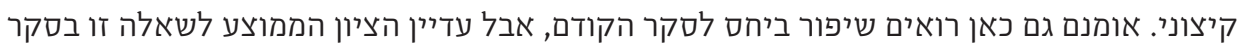
הנוכחי היה 3.5, מהנמוכים ביותר בכל הסקר. 
במוסדות רבים הופנו משאבים לבניית נוהל קליטה מסודר הכולל ימי עיון לנקלטים והדרכות במגוון

נושאים. המסקנה העיקרית מתוצאות הסקר היא שהמאמץ המופנה לשיפור תהליך הקליטה נושא

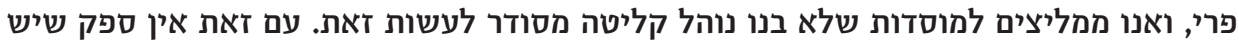
עוד מקום רב לשיפור, בייחוד בכל הנוגע להדרכה בניהול קבוצת מחקר והכנה לתפקידים ניהוליים.

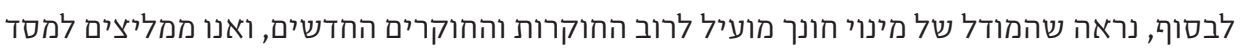

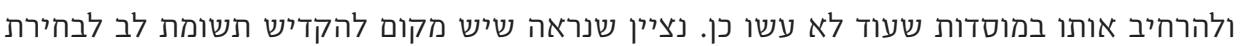
החונכים, להגדיר את תפקידם, לפקח עליהם ואולי אף לקיים סדנאות הכנה לחונכים.

תרשים 6 א. שיעור החוקרים שהוצמד להם חונך

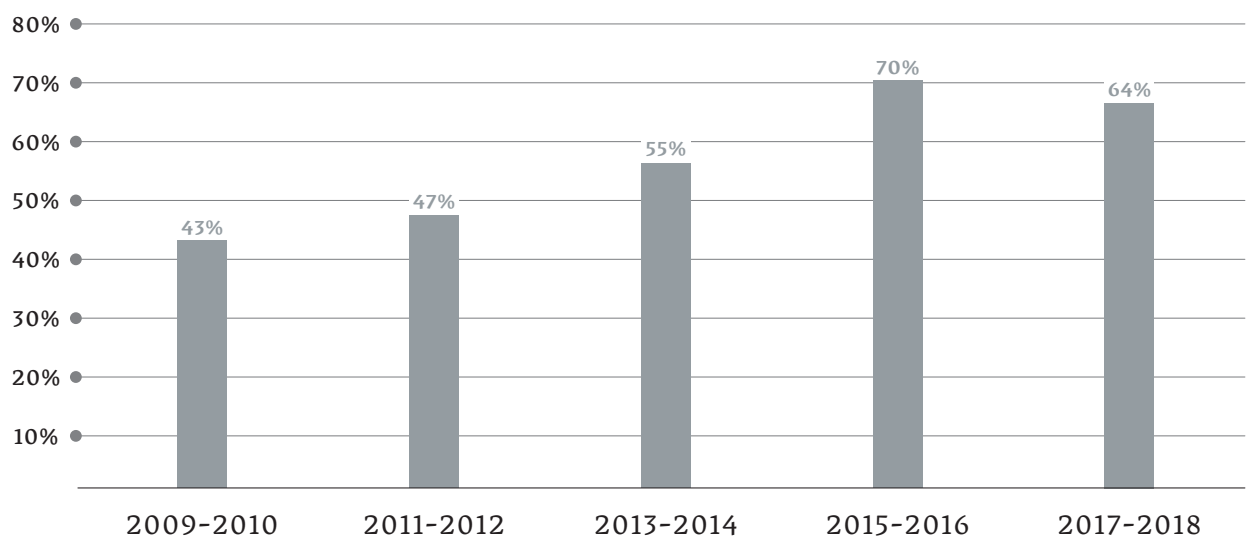

תרשים 6 ב. באיזו מידה הקשר עם החונך הועיל לך? (ממוצע ציונים בין 0 ל־10) מאוד 10

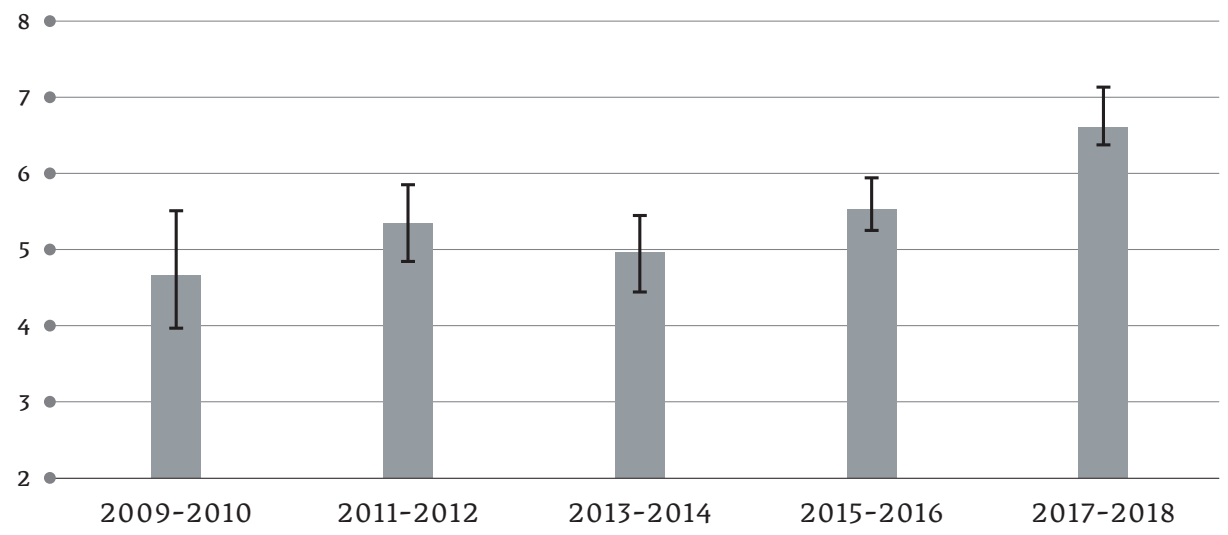




\section{(0)7 \\ משאבים ותשתיות}

בסקר שאלנו כמה שאלות על מידת התאמת המעטפת הניתנת לחברי הסגל הנקלטים לצורכי המחקר שלהם. רוב הנשאלים דיווחו כי תשתיות המעטפת, כגון שירותי מחקר, בתי מלאכה, גרפיקה וכד',

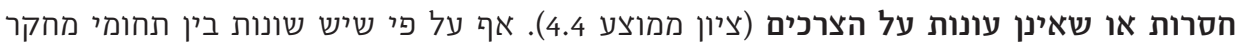
ובין מוסדות, נראה שזו בעיה רחבה הקיימת במרבית המוסדות. בקצה החיובי מופיעים הספריות ומאגרי המידע המקוונים: רוב הנשאלים דיווחו שאלו עונים על הצרכים המחקריים שלהם (ציונים

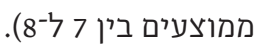

נושא שבלט כבעייתי הוא תשתיות הנדל"ן וזמינות המשרדים והמעבדות. אומנם כמעט כל החוקרים קיבלו משרדים אשר על פי רוב תאמו את צורכיהם, אבל עבור 31\% מהמשיבים המשרד לא היה מוכן בזמן. כמו כן רק שליש מהחוקרים שקיבלו מעבדה זכו לקבלה בזמן. שני השלישים האחרים

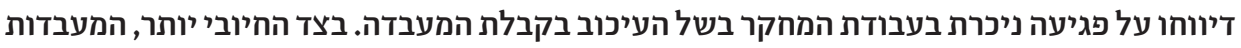
שהועמדו לרשות החוקרים הזקוקים לכך תאמו על פי רוב את צורכיהם.

אנו מבינים כי שיפור תשתיות המחקר דורש השקעה כספית רבה אשר לא תמיד אפשר לגייסה. לעומת זאת ייתכן שבעיכובים שבמסירת המעבדות ניתן להשיג שיפור גם ללא השקעה כספית

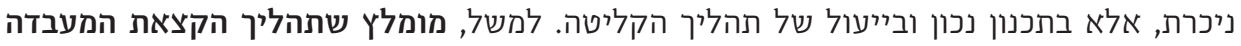

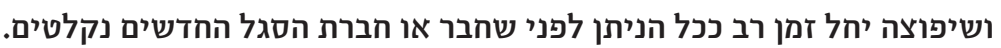


תרשים 7. ממוצעי תשובות לשאלות בנוגע לתשתיות מחקר מוסדיות (ממוצע ציונים בין 0 ל־10)

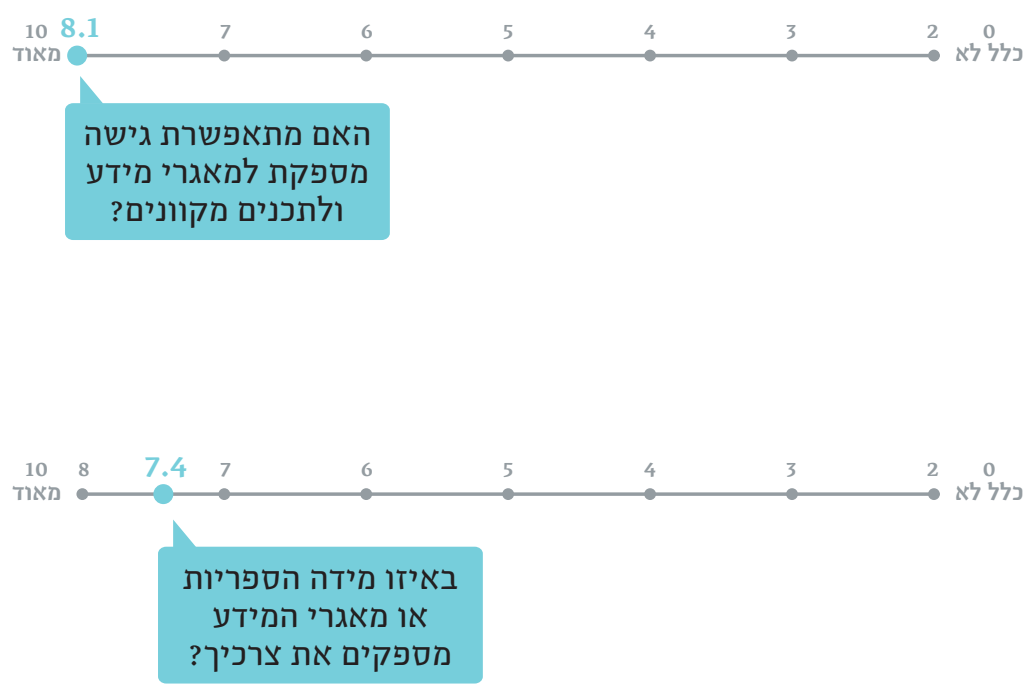

האם קיבלת משרד?

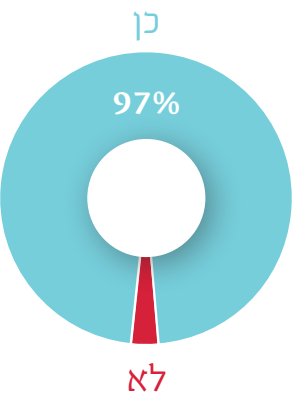

האם המשרד שהועמד

לרשותך היה מוכן בזמן?
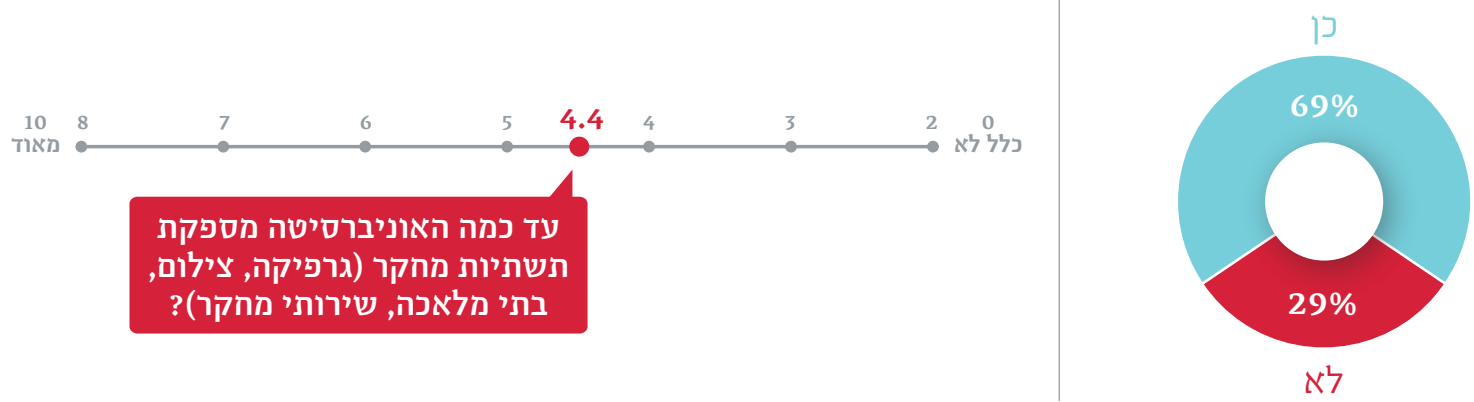

האם השטח שהועמד

לרשותך היה מוכן בזמן?
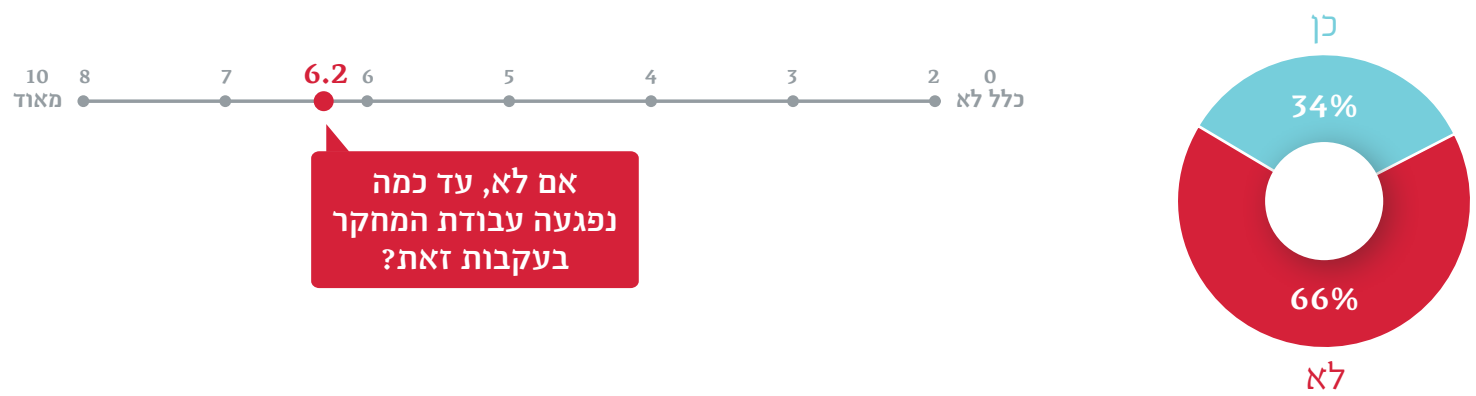


\section{עומס עבודה שאינה מחקרית}

משרה אקדמית כוללת כמות לא מבוטלת של עבודה שאיננה מחקרית, כמו הוראה, כהונה בוועדות

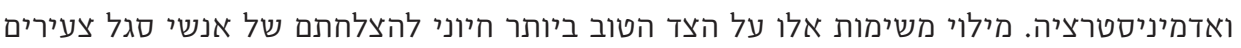

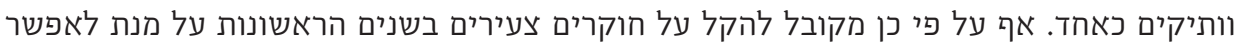

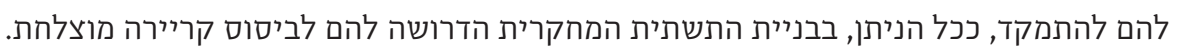

מהסקר עולה כי עומס ההוראה משתנה מאוד בין הפקולטות השונות. חוקרים וחוקרות במדעי הרוח

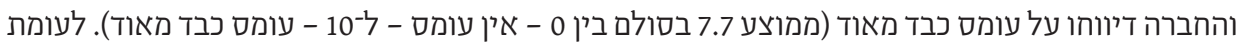
זאת במדעים מדויקים העומס הוא בינוני-גבוה (ממוצע 6.2), ובמדעי החיים העומס בינוני (ממוצע 4.7 4.9).

ניכר הבדל גדול גם בהקלות שקיבלו חוקרות וחוקרים בפקולטות שונות בהוראה בשנה הראשונה.

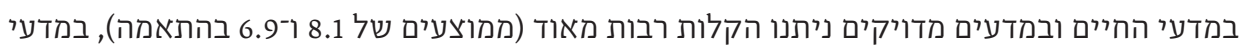
החברה ניתנו מעט פחות הקלות (ממוצע 5.2), ובמדעי הרוח כמעט שלא ניתנו הקלות (ממוצע 3.8). נתון מעודד הוא שבמדעי הרוח רואים שיפור מתמיד לאורך העשור האחרון בהקלות בהוראה

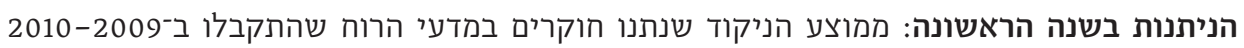
לשאלה זו הוא 1.6, ולעומתו, הממוצע של חוקרים שהתקבלו ב־2017-2018 הוא 5.

עבודה לא מחקרית, כגון כהונה בוועדות, גם היא מטילה עומס שאינו זניח. הציון הממוצע שניתן

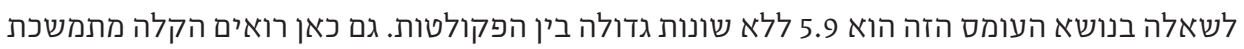
בעומס לפי שנת הקבלה כאשר הממוצע הוא 6.9 לחוקרים שהתקבלו ב־2009-2010 לעומת 4.9

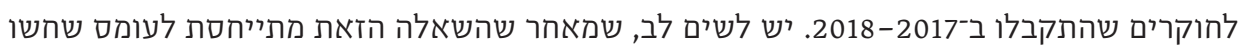
הנשאלים בתקופה שבה מילאו את הסקר, תוצאה זו אינה מעידה בהכרח על שינוי עם השנים

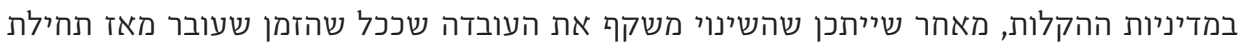
המסלול לקביעות רב יותר, כך עולה עומס העבודה הלא־מדעית. מכל מקום, זהו נתון מעודד. 
קבוצה חריגה בעומס המוטל בשל כהונה בוועדות היא נשים במדעים מדויקים, בהנדסה ובמדעי החיים. נשים במקצועות אלו מדווחות על עומס חריג (6.2) לעומת הגברים (4.8). שאלה זו היא מהשאלות היחידות שבהן מופיע פער מגדרי בתחומים אלו (ראו בפרק העוסק בפערים מגדריים).

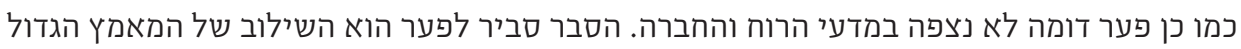
לייצוג נשי בוועדות ובתפקידי מפתח עם שיעורן הנמוך של נשים במקצועות אלו.

המסקנה הכללית מתוצאות הסקר בנושא זה היא שהמוסדות מכירים בצורך להקל על חוקרות וחוקרים בשנותיהם הראשונות, ושהמאמץ בנושא נותן תוצאות. אולם נראה שעדיין יש מקום לשיפור במימוש ההקלות, במיוחד במדעי הרוח והחברה. תרשים 8 א. עד כמה מכסת ההוראה משפיעה על יכולתך לחקור? (ממוצע ציונים בין 0 ל־10) מאוד 10

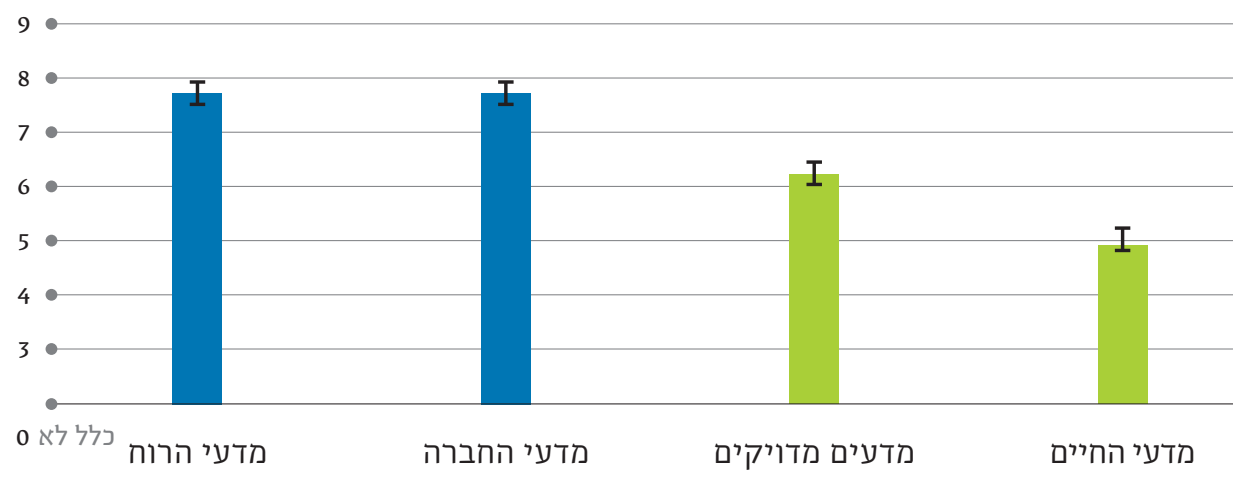

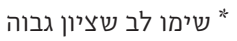

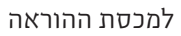
משמעותו עומס כבד

תרשים 8 ב. עד כמה קיבלת הקלות במכסת ההוראה בשנה הראשונה להגעתך? (ממוצע ציונים בין 0 ל־10 כמדים (מרים מאוד 10

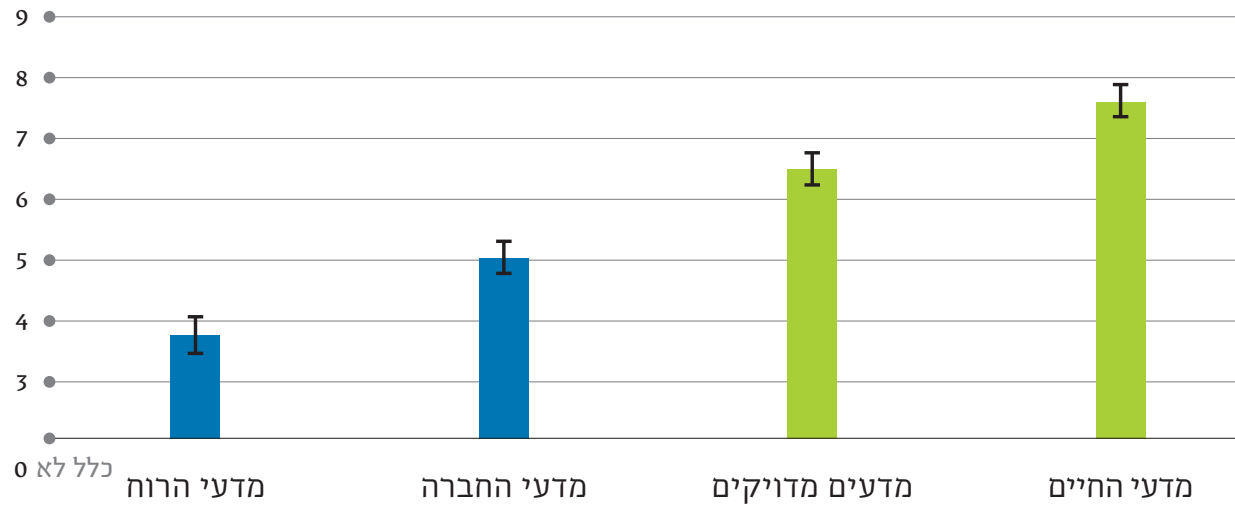

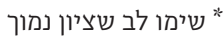

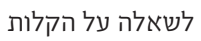
משמעותו מעט הקלות הקלת 
אחד האתגרים הגדולים העומדים בפני חוקרים וחוקרות בתחילת דרכם הוא השגת מימון מספיק לביצוע המחקר. מימון זה מתקבל מקרנות חיצוניות וממקורות פנים־מוסדיים. ברוב המוסדות רוב

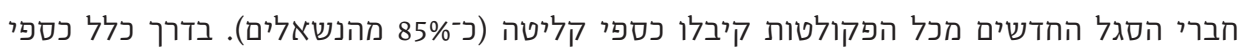
הקליטה מאפשרים התנעה של המחקר, אולם כשליש מהחוקרים שקיבלו מענק קליטה מדווחים שכספי המענק לא הספיקו לצורכיהם (ציון 5 ומטה). בעיה זו בולטת בעיקר אצל חוקרים ממדעי

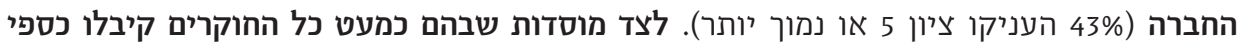
קליטה, יש מוסדות שבהם חלק גדול מהנקלטים ממדעי הרוח והחברה לא קיבלו מענק קליטה כלל.

לאחר הקליטה הסיכוי לקבל סיוע של המוסד במימון דוקטורנטים שונה מאוד מתחום לתחום. במדעי החיים 97\% מהחוקרים קיבלו סיוע כזה, במדעים המדויקים 74\%, במדעי החברה 32\% ובמדעי הרוח רק 14\%. אין מקורו של הפער הזה בעובדה שהחוקרים במדעי החברה והרוח בדרך כלל אינם זקוקים לדוקטורנטים לצורך המחקר. כמחצית מאלה שלא קיבלו סיוע בתחומים הללו דיווחו

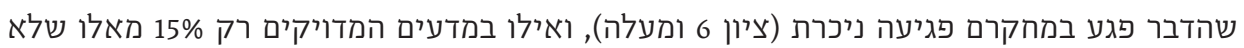
קיבלו סיוע דיווחו על פגיעה במחקרם.

סיוע במימון בתר־דוקטורנטים נפוץ פחות, אבל גם כאן יש פער בין התחומים. רק 10\% מהמשיבים במדעי הרוח והחברה קיבלו מהמוסד סיוע, לעומת 40\% מהחוקרים במדעי החיים ובמדעים המדויקים. רוב החוקרים שקיבלו סיוע במימון בתר־דוקטורנטים (68\%) דיווחו שסיוע זה תרם רבות להצלחת המחקר שלהם (ציון 6 ומעלה). לצד הסיוע במימון סטודנטים מרבית החוקרים הצעירים קיבלו סיוע ברכישת ציוד וחומרים (ציון ממוצע 5.7) וסיוע מועט מזה במימון הוצאות מחקריות

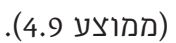


לבסוף, נוסף על המימון המוסדי החוקרים פונים כמובן לקרנות חיצוניות בבקשת סיוע כספי. מרביתם מדווחים שמענקי המחקר שקיבלו מספיקים למימון המלגות והמשכורות הדרושות לקבוצת המחקר

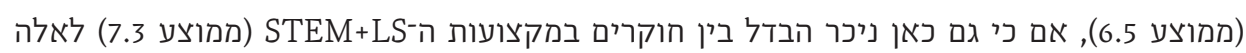

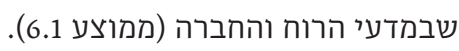

לרבים מהחוקרות והחוקרים הצעירים יש מקורות מימון מספיקים (פנימיים וחיצוניים) לצורך

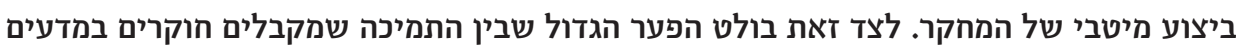

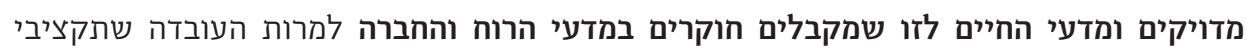

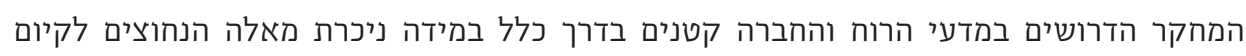

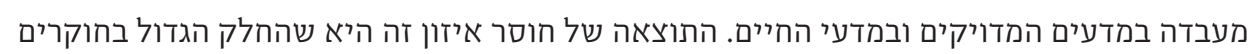

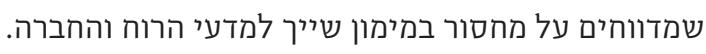

תרשים 9 א. שיעור החוקרים שקיבלו תמיכה בנושאים שונים (קליטה, דוקטורנטים ובתר־דוקטורנטים) בתחומי דעת שועים שונים תחיבים

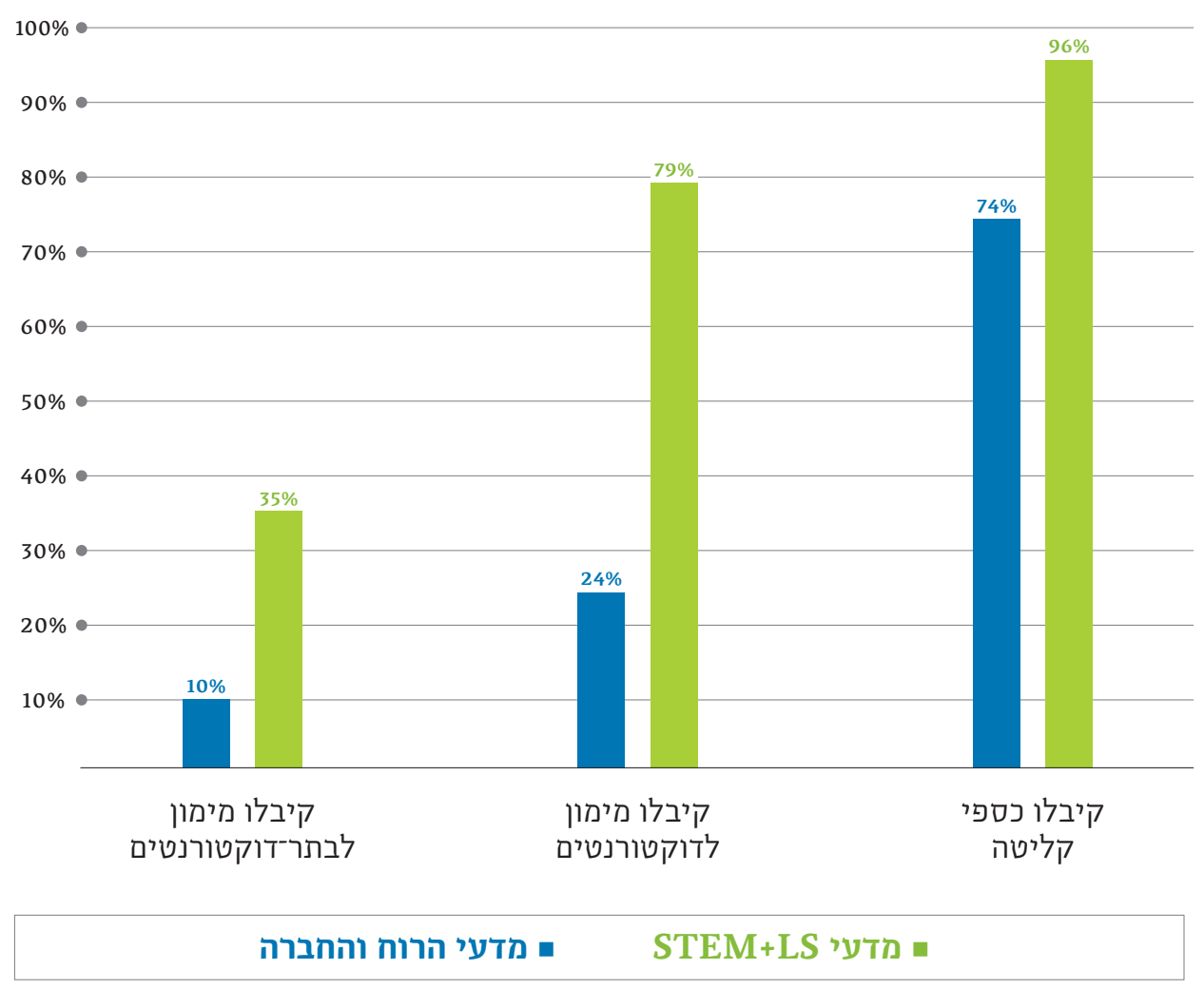


תרשים 9 ב. ממוצאי התשובות לשאלות הנוגעות למימון בחלוקה לפי תחומי דעת (ממוצע ציונים בין 0 ל־10) מאוד 10

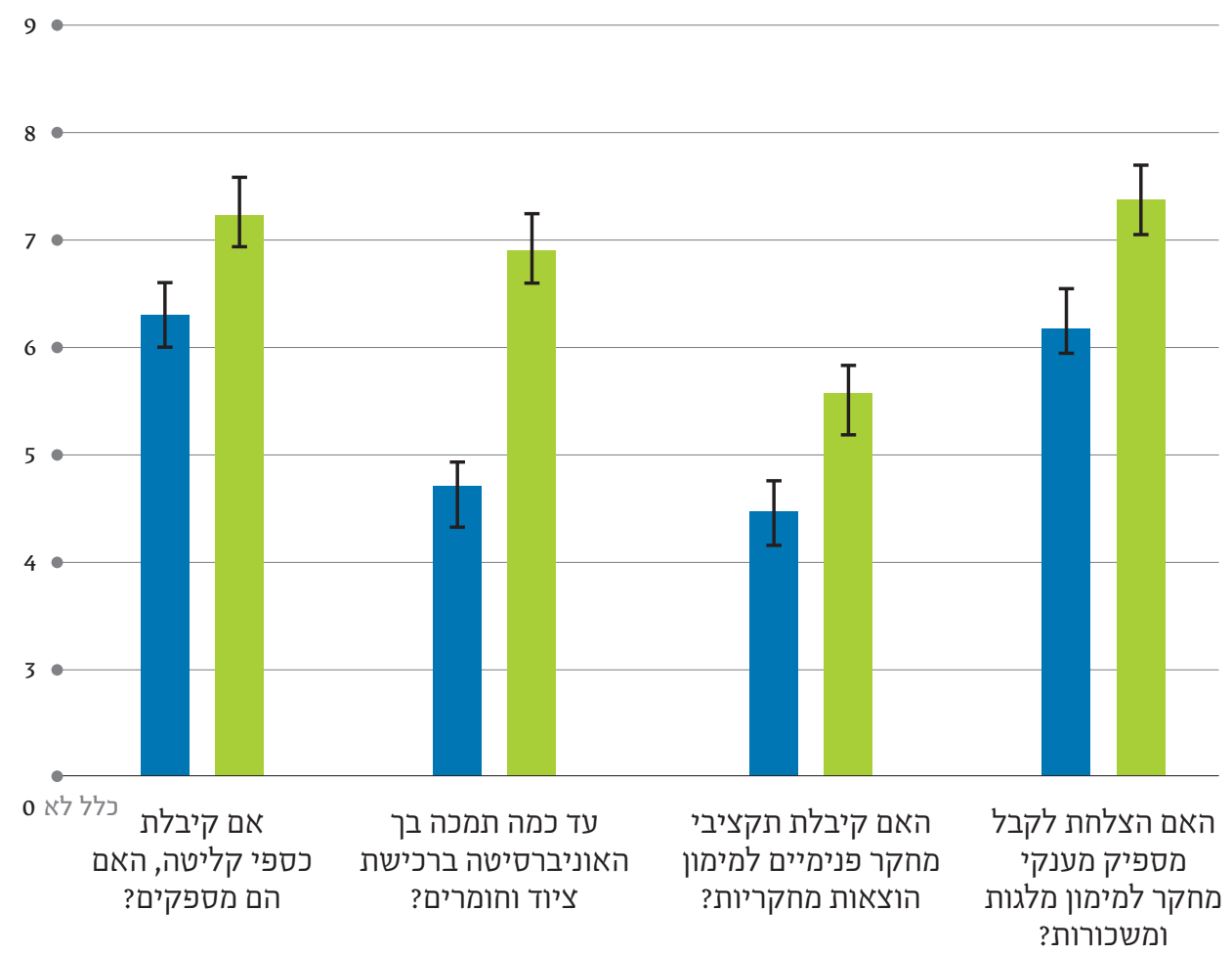




\section{המערכת האדמיניסטרטיבית}

הציונים שניתנו בסקר לשאלות שנגעו למערכת האדמיניסטרטיבית נמוכים במידה ניכרת מהממוצע

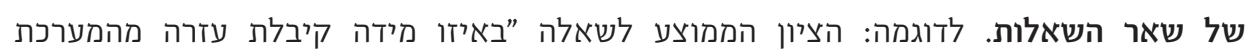
האדמיניסטרטיבית במחלקה שלך בנושאים שקשורים למחקר ולהגשות קרנות מחקר?" הוא 3.9, כאשר 25\% מהמשיבים נתנו את הציון 0 - הנמוך ביותר. בשאלה דומה על הסיוע המחלקתי בנושאים

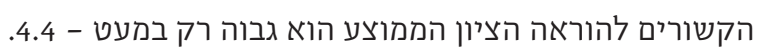

תוצאה זו מעידה שמערכת זו מקשה את המחקר ואת ההוראה של רבים מהמשיבים. התוצאות הללו

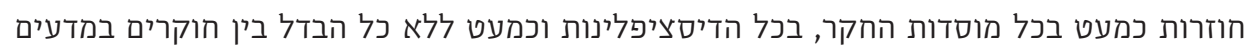
העיוניים לאלה הניסויים. מרבית החוקרים הצעירים אינם מקבלים סיוע, ויתרה מזאת, הם חווים קשיים בהתמודדותם עם

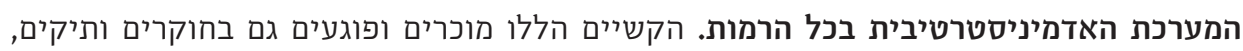

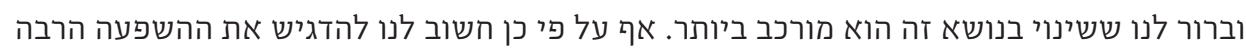

שיש לנושא על חוקרים צעירים ואת העובדה שלא נצפה כל שיפור בנושא מאז הסקר הקודם.

תרשים 10. ממוצע ציונים לשאלות הנוגעות למערכת האדמיניסטרטיבית (ממוצע ציונים בין 0 ל־10)
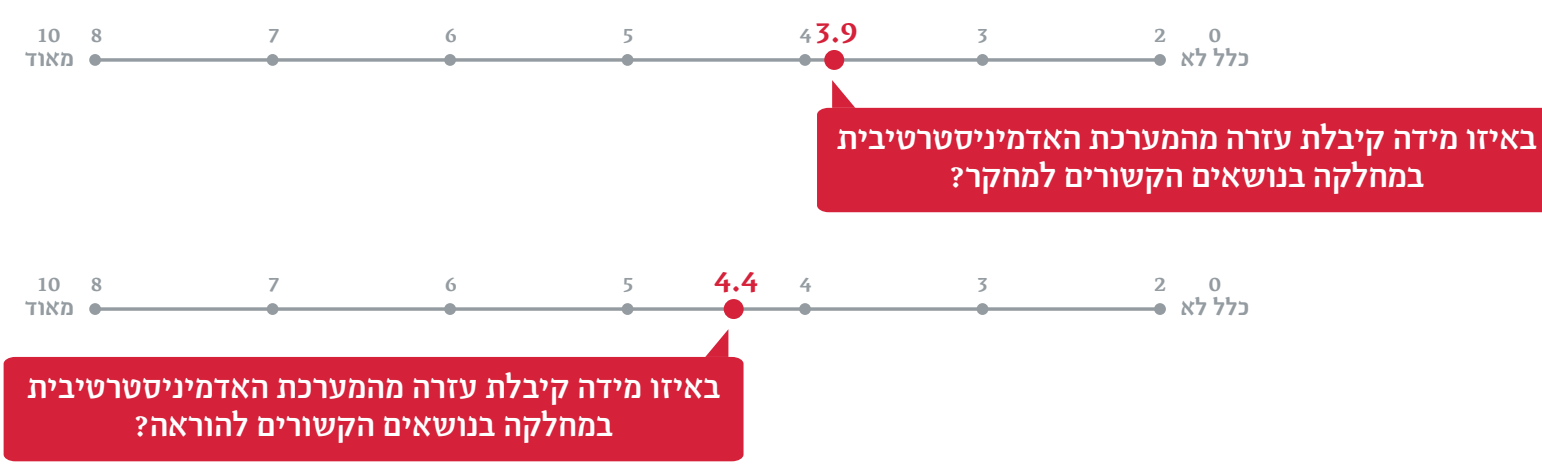
המשתתפים בסקר נשאלו אם הם שייכים לקבוצת מיעוט, ואם כן - אם עובדה זו השפיעה על היחס

כלפיהם (לטובה או לרעה).

בנוגע לשתיים מקבוצות המיעוט (מגדר ומוצא אתני) אפשר לנו המידע הדמוגרפי שנאסף בסקר

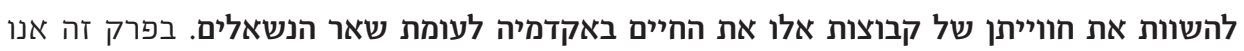

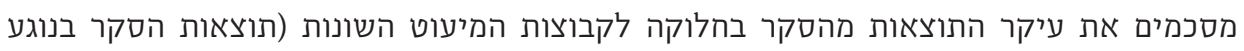
למגדר מובאות בפרק נפרד המוקדש לנושא זה).

69\% מהמשיבים לסקר הגדירו את עצמם יהודים ממוצא אשכנזי, 27\% הגדירו את עצמם יהודים

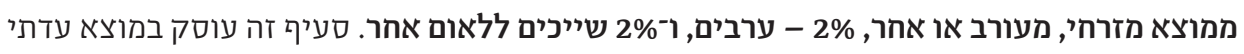

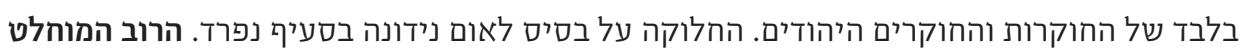
של היהודים הלא אשכנזים (92\%) אינם רואים את עצמם שייכים לקבוצת מיעוט על בסיס עדה. גם מה־8\% שרואים את עצמם מיעוט עדתי הרוב מציין שהיחס אליו לא הושפע מזה כלל. מכלל המשיבים לסקר רק 6 משיבים מרגישים שהיחס אליהם הושפע לרעה על בסיס שיוך עדתי.

בניתוח תוצאות הסקר לא מצאנו הבדל דמוגרפי חוץ־אקדמי ניכר בין יהודים אשכנזים ללא אשכנזים שיכול להטות את הסקר. הממוצעים של הגיל, המצב המשפחתי ומספר הילדים של חוקרים וחוקרות משתי הקבוצות דומים מאוד. גם בחלוקה דמוגרפית לפי מאפיינים אקדמיים הקבוצות כמעט זהות.

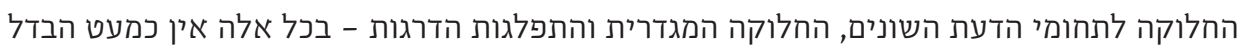

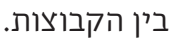
גם התשובות לשאלות השונות של חוקרים אשכנזים וחוקרים ממוצא מזרחי ומעורב היו דומות מאוד. הממוצעים של הרוב המוחלט של השאלות היו כמעט זהים (ההבדלים היו קטנים משתי שגיאות תקן של הממוצע), כאשר בחלק מהשאלות הממוצע של האשכנזים טוב יותר, ובחלק להפך. בסך 
הכול, לא נמצאה אף שאלה אחת שיש בה פער ניכר בין אשכנזים ללא אשכנזים. תוצאות דומות (הן מבחינה דמוגרפית והן מבחינת השאלות) התקבלו גם כאשר הפרדנו את קבוצת המזרחים והמעורבים

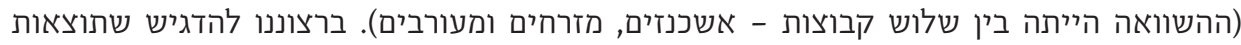
הסקר מעידות שהוא רגיש לפערים בחוויה האקדמית בין קבוצות דמוגרפיות שונות, כאשר אלו קיימים. פערים כאלו נמצאו בכל חלוקה דמוגרפית שבה סביר למצוא פערים (לפי דיסציפלינה, מוסד, מגדר, דרגה אקדמית, קביעות, שנת קבלה, גיל), אך לא נמצאו בחלוקה על בסיס מוצא עדתי.

\section{לסיכום, מהסקר עולה פער בייצוג בין קבוצות אתניות שונות, ואולם אין הבדלים מכל סוג שהוא בחוויה האקדמית של חוקרות וחוקרים צעירים בין הקבוצות האתניות השונות.}

רק מספר קטן של המשיבים הגדירו את עצמם שייכים לכל אחת מהקטגוריות הנוספות של קבוצות מיעוט שעליהן שאלנו. מספרים אלו אינם מאפשרים גזירה מהימנה של תוצאות בעלות מובהקות

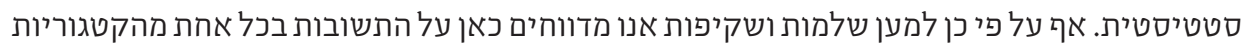

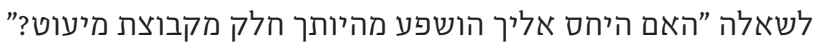
בסך הכול 28 משיבים, שהם קצת יותר מ־3\% מכלל המשיבים, דיווחו על עצמם שהם שייכים ללאום לאום

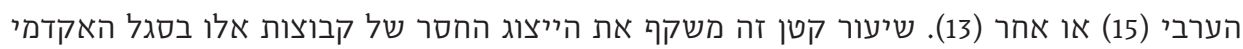
בכלל בישראל. רק ערבים הגדירו את עצמם מיעוט, ובסך הכול 12 מהם עשו זאת (בני לאומים אחרים וחלק מבני הלאום הערבי לא הגדירו עצמם שייכים לקבוצת מיעוט). מבחינת היחס אל המשיביבים ובסים שמרגישים שייכים לקבוצת מיעוט על בסיס לאום, 3 השיבו שהיחס אליהם הושפע לטובה, 4 השיבו שהוא הושפע לרעה, ו־5 השיבו שלא הושפע כלל. 31 מהמשיבים לסקר (כ־3\%) הגדירו את עצמם שייכים לקבוצת מיעוט זו. 28 השיבו שהיחס אליהם

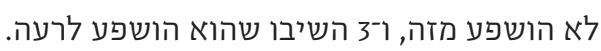

13 מהמשיבים לסקר (כ־1.5\%) הגדירו את עצמם שייכים לקבוצת מיעוט זו. 9 השיבו שהיחס אליהם ת לא הושפע מזה, 3 השיבו שהוא הושפע לרעה, ו־1 השיב/ה שהוא הושפע לטובה. 9 מהמשיבים לסקר הגדירו את עצמם שייכים לקבוצת מיעוט זו. 6 השיבו שהיחס אליהם לא הושפע מוגבלות מזה, ו־3 השיבו שהוא הושפע לטובה. בשאלון נתנו מקום להוסיף בטקסט חופשי שייכות לקבוצות מיעוט נוספות. כ־30 משיבים שייכו אחר את עצמם לקבוצת מיעוט אחרת: 8 מתוכם לעולים חדשים או ותיקים, 5 להורים יחידנים ו־4 להורים לילדים בעלי צרכים מיוחדים. 
הסקר כלל ארבעה סוגים שונים של שאלות הרלוונטיות לנושא - דמוגרפיה, חוויות שונות שאינן

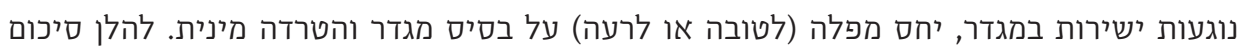
תוצאות הסקר בנושאים אלה. מגדר ודיסציפלינה בסקר משתקפים פערי הייצוג המגדרי הידועים בין תחומי הדעת. תרשים 11. ייצוג מגדרי לפי תחומי דעת

כללי

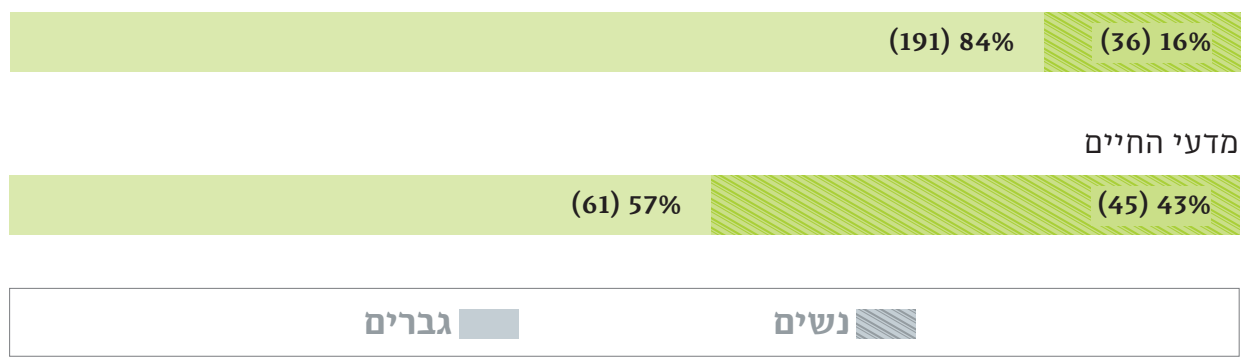


הייצוג המגדרי של המשיבים לסקר בחלוקה דיסציפלינרית דומה מאוד לנתוני מל"ג על סגל שנקלט בין השנים 2015 ל־2018. עובדה זו מעלה את הסיכוי שהמדגם בסקר הוא מייצג. בהקשר של ניתוח הסקר לפערי ייצוג אלו חשיבות גדולה. כפי שתיארנו בפרק שעוסק בתחומי הדעת השונים, יש פער בין הדיסציפלינות השונות כמעט בכל אחד מהנושאים שעליהם שאלנו. פער זה גדול בהרבה

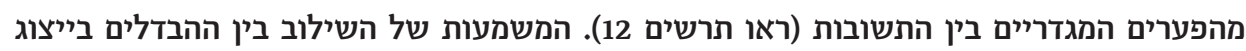

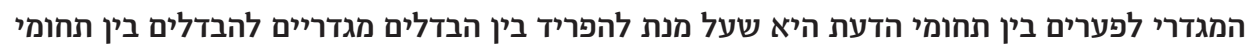

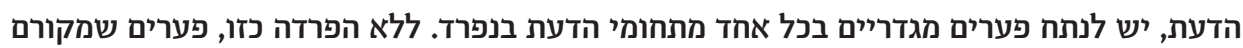
דיסציפלינרי ביסודו יפורשו בטעות כפערים שמקורם מגדרי. לכן ביצענו את ניתוח הפערים המגדריים בשתי קבוצות נפרדות - מדעי החיים, מדעים מדויקים והנדסה (STEM+LS) ומדעי הרוח והחברה.

\section{דמוגרפילה}

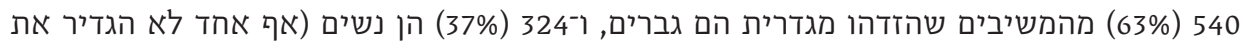

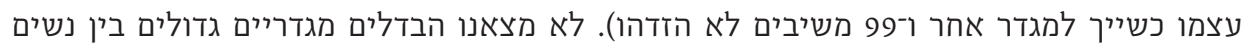

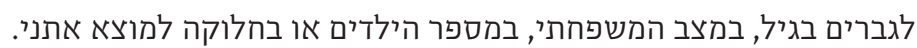
בניתוח של מדעי הרוח והחברה מוצאים כמה הבדלים. תחילה נמצא הבדל בדרגת הקבלה בין גברים

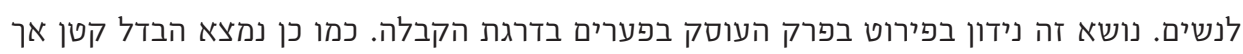
מדעי הרוחה

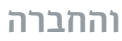

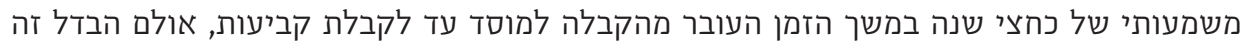

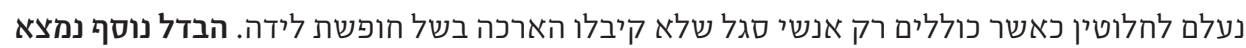

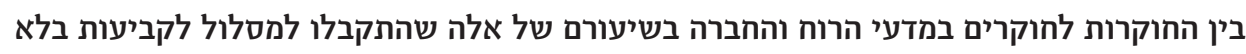
שעברו כל הכשרה (דוקטורט או בתר־דוקטורט) בחו"ל - 24\% מהנשים ו־12\% מהגברים. השוואה של המאפיינים הדמוגרפיים האקדמיים (דרגת קבלה, קביעות, זמן לקידום וכד') בין גברים לנשים במדעי ה־STEM+LS אינה מעלה הבדלים משמעותיים.

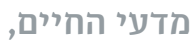
מדעים מדויקים

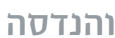

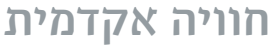

ההשוואה המגדרית בחוויה האקדמית גם היא בעלת משמעות אך ורק כאשר היא מתבצעת בכל דיסציפלינה בנפרד, מאחר שהפערים בחוויה בין תחומי הדעת גדולים בהרבה מהפערים המגדריים

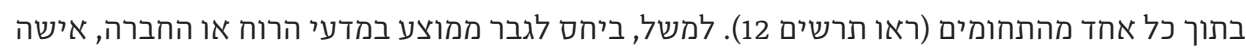

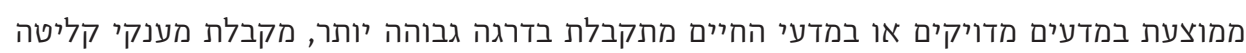

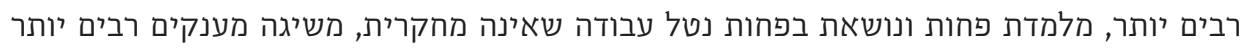
למימון סטודנטים, זוכה לתמיכה רב יותר מהמערכת המחלקתית ומהעמיתים הצעירים, הליך הקידום שלה יעיל ושקוף יותר והקריטריונים ברורים לה יותר ועוד. פער דומה (הפעם עם עדיפות לגברים) מתקבל כאשר משווים נשים במדעי הרוח והחברה לגברים במדעי החיים ובמדעים מדויקים. 
השיבו לסקר 131 נשים ו־148 גברים ממדעי הרוח והחברה. הסקר מעיד שבתחומים אלו יש כמה נושאים שבהם הנשים מדווחות על קשיים רבים מאלה שעליהם מדווחים הגברים. המסקנה היא

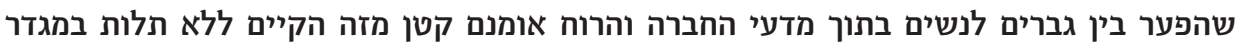
בין דיסציפלינות אלה לבין מקצועות ה־STEM+LS, אולם הוא נוכח ועקבי. הנושאים העיקריים

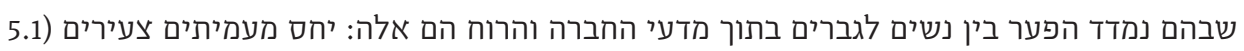

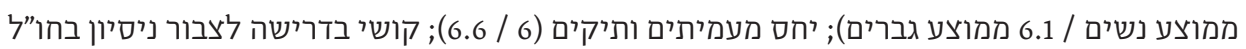
(3.4 / 2.3); עזרה מהמערכת האדמיניסטרטיבית המחלקתית בנושאים שקשורים למחקר (3.1 / 3.8);

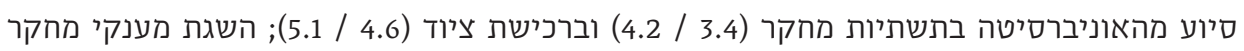
מספיקים למימון מלגות ומשכורות (6 / 6.5).

לסקר השיבו 81 נשים ו־252 גברים ממדעי החיים, ממדעים מדויקים ומהנדסה. פער ייצוג מגדרי זה

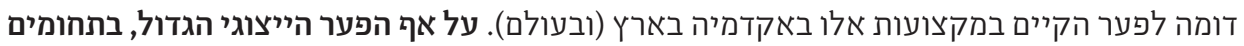

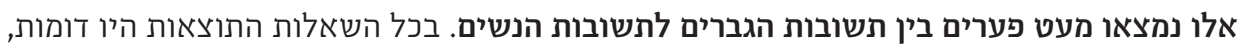

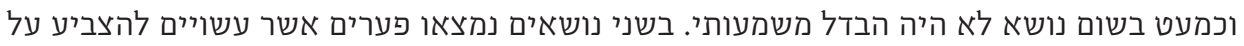

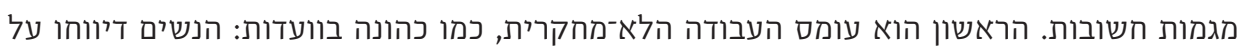

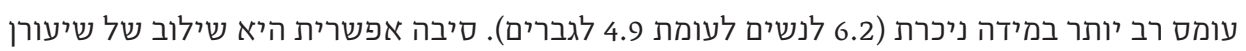

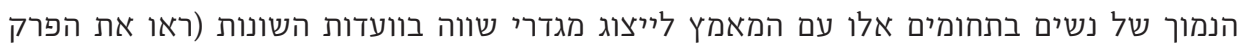
בנושא). הנושא השני הוא קביעות וקידום: נשים נתנו ציונים מעט גבוהים יותר מאלה שנתנו גברים

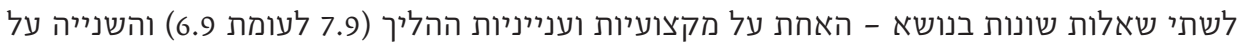
מהירותו ויעילותו (5.6 לעומת 4.8).

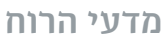

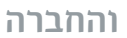

* תרשים 12. (בעמוד הבא) סטיית הציון הממוצע של קבוצות שונות (לפי חלוקה מגדרית ודיסציפלינרית)

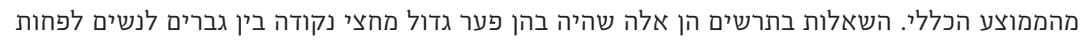

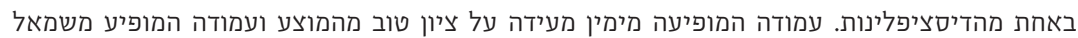

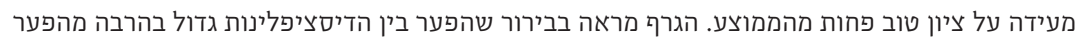

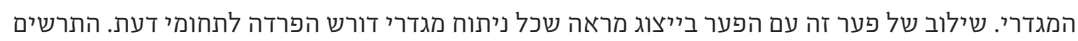

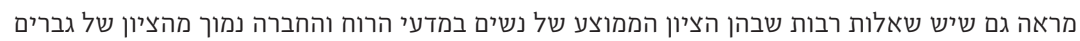
בתחומים אלו. לעומת זאת במקצועות ה־STEM+LS ברוב השאלות אין פער מגדרי, וכאשר פער כזה ליות קיים, לעיתים יש עדיפות לנשים ולעומת במקיתים לגברים. 
תרשים 12. סטיית הציון הממוצע של קבוצות שונות (לפי חלוקה מגדרית ודיסציפלינרית)

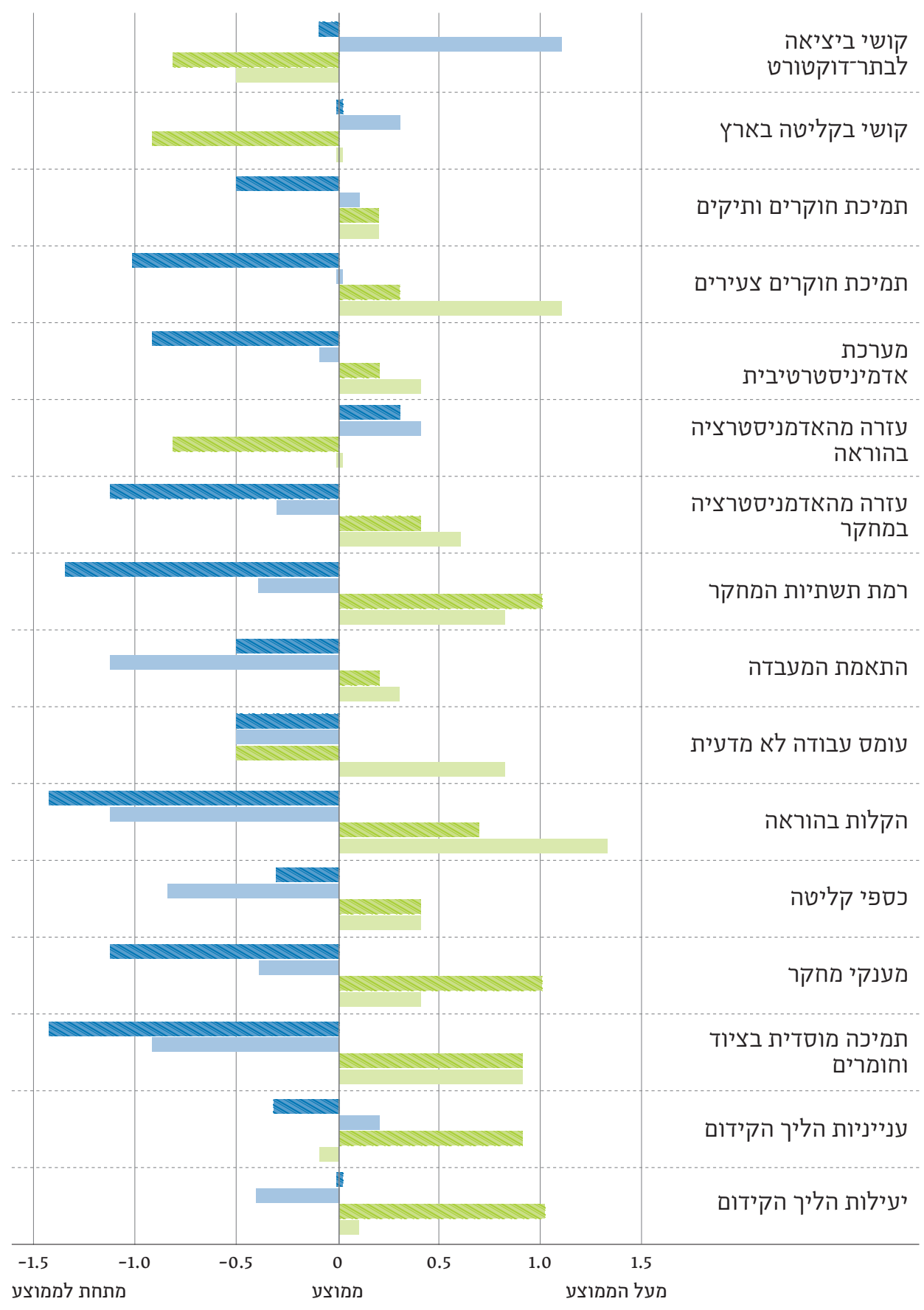

גש: נשים מדעי הרוח והחברה

STEM+LS גוש נשים מדעי מדעי גברים מדעי הרוח והחברה הרוח ווהחרה גברים מדעי STEM+LS נשים מדעי 


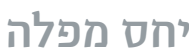

בסקר נכללו שאלות על היחס לקבוצת מיעוט גם בהקשר המגדרי. 94 מהנשים (כ־30\% מכלל המשיבות לסקר) הגדירו את עצמן שייכות לקבוצת מיעוט על בסיס מגדר. 70\% מהמשיבות לקלות לא הגדירו עצמן

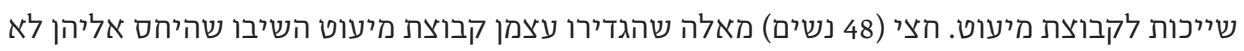

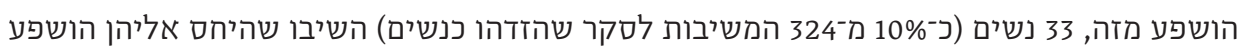
לרעה, ו־12 (4\%) השיבו שהיחס אליהן הושפע לטובה.

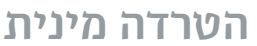

בסקר שאלנו "האם חווית הטרדה מינית באוניברסיטה?" לשאלה זו ענו 863 מהנשאלים כאשר 533 כשינים

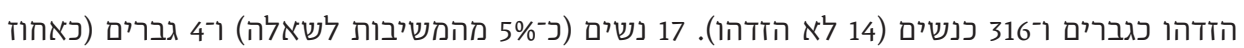
מהמשיבים) ענו שחוו הטרדה מינית. את המשיבים בחיוב שאלנו אם יכלו לנקוט פעולה כלשהי בתגובה להטרדה וביקשנו לפרט את הפעולה, אם ננקטה, ואם לא - את הסיבה שבגינה לא פעלו.

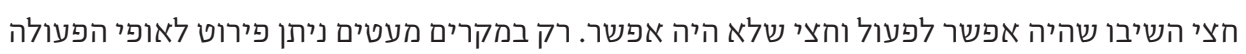

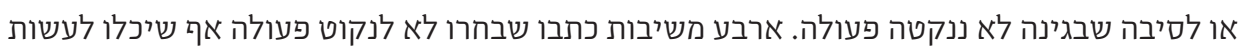
זאת. שלוש אחרות ענו שלא יכלו להתלונן מאחר שחששו מהתוצאות (למשל חשש מבעיות בקידום).

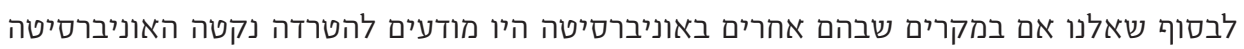
את כל הצעדים הדרושים. שלושה גברים וארבע נשים השיבו שאחרים באוניברסיטה היו מודעים להטרדה, ואף על פי כן לא ננקט הצעד הדרוש - טיפול במטריד/ה כמתחייב מכוח החוק. 


\section{3 \\ התפתחות בציר הזמן והשוואה לסקר הקודם הציר הזות}

כרבע מהשאלות בסקר הנוכחי, הכוללות את רוב הנושאים המרכזיים, היו זהות לשאלות שנשאלו

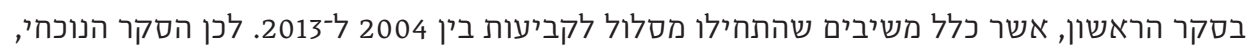
בשילוב עם הסקר הקודם, מאפשר לנו לבחון את ההתפתחות לאורך יותר מעשור (בין 2004 ל־2018)

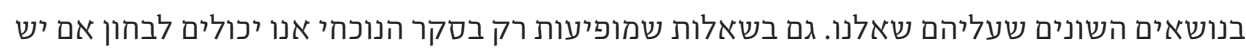
הבדל בתשובות בין משיבים שהתקבלו לאוניברסיטה בשנים שונות.

בסך הכול נצפו מעט שינויים לאורך הזמן. מתוך 14 שאלות זהות בשני הסקרים רק בשלוש שאלות

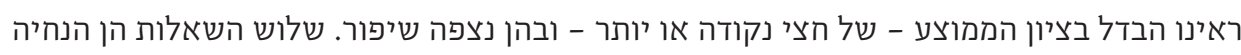

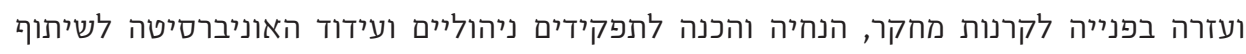

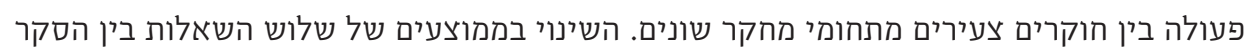

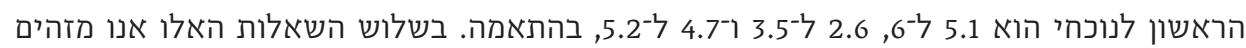
שיפור מובהק ומתמשך גם בבחינת השינוי בזמן בסקר הנוכחי בלבד, ולכן אנו בטוחים למדי שאכן בנושאים אלו יש שיפור מתמשך (ראו תרשים 13).

גם בבחינתן של שאלות שהופיעו רק בסקר השני (בין 2009 ל־2018) אנו מוצאים מעט שאלות שיש בהן שינוי לאורך הזמן, וגם כאן בכל השאלות שבהן נצפה שינוי, הוא חיובי. למשל: בתמיכתם של חוקרים

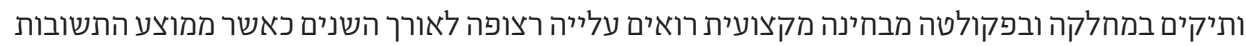

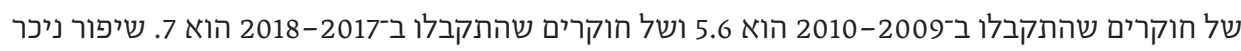
ומתמשך אנו מוצאים גם בשיעור החוקרים שמונה להם חונך (ראו דיון בפרק על הנחיה והדרכה). סביר

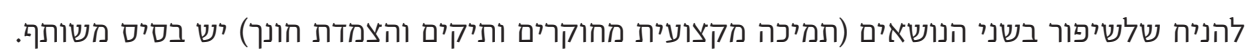
המשותף לשתי שאלות אלו ולשתיים משלוש השאלות שבהן רואים שיפור בין הסקרים הוא שכולן

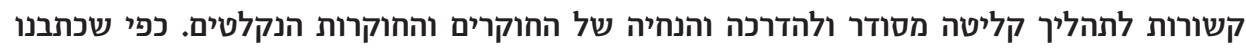
בפרק המוקדש לנושא, עולה מהסקר שהשקעתם הניכרת של המוסדות בנושא זה נושאת פרי. 
נושא נוסף שבו אנו רואים שיפור, אם כי לא בכל השאלות הנוגעות בו, הוא תקציבי מחקר פנימיים. כאן אנו רואים שיפור לאורך שנות הסקר הנוכחי בשתי שאלות: הציון הממוצע לקבלת תקציבי מחקר פנימיים של האוניברסיטה למימון הוצאות מחקריות עלה מ־4.1 ב־2009-2010 ל־5.4 ב־2017-2018.

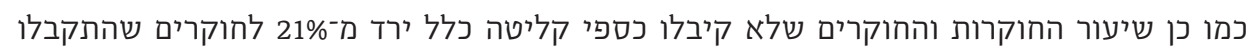

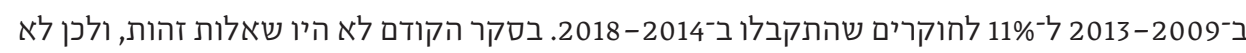
ניתן לבצע השוואה מדויקת בין הסקרים, אולם בסקר הקודם לא נמצאה כל התפתחות בזמן בשאלות דומות שעסקו בתקציבי מחקר פנימיים.

מלבד אלה, אין הסקר מצביע על התפתחות בזמן בנושאים אחרים. הדבר מראה שברוב הנושאים

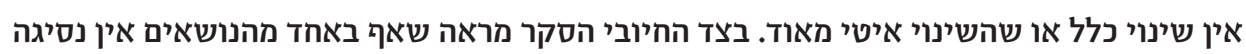

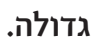

תרשים 13. ממוצע התשובות לשאלה על הנחיה בפנייה לקרנות בחלוקה לפי שנת

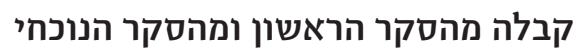

מאוד 10

8

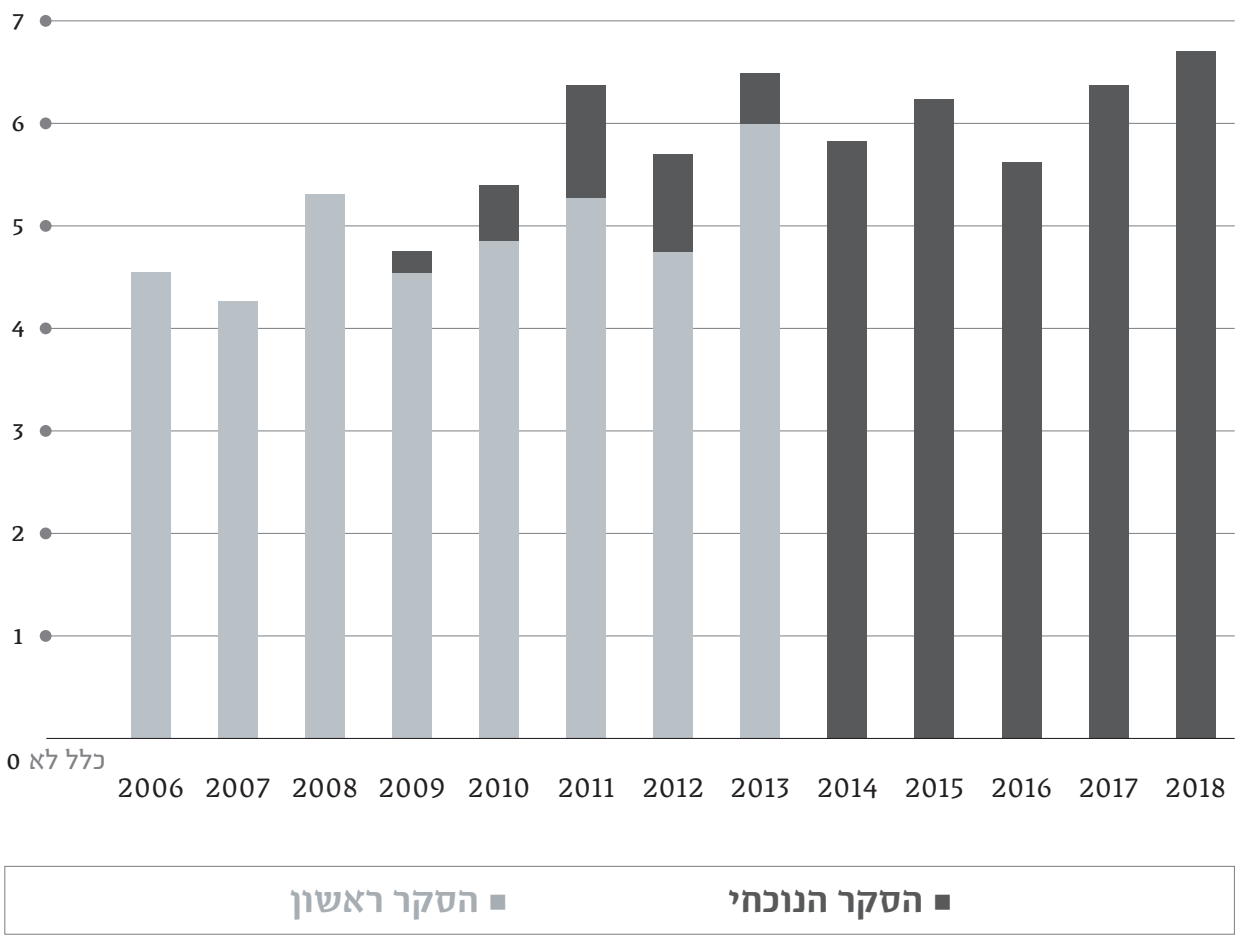


נספחים 


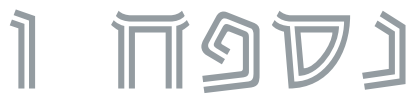

\section{השאלון המלא ותוצאותיו}

\begin{tabular}{|c|c|c|c|c|}
\hline מס' משיבים & 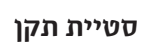 & חציון & 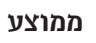 & \\
\hline 937 & 3.45 & 2 & 3.39 & מנת להתה הקשל למסל עליך הדרישה לצבור ניסיון בחו"ל (PhD או בתר־דוקטורט) על \\
\hline 743 & 3.38 & 3 & 3.98 & עד כמה הקשתה שהייתך בחו"ל (PhD או בתר־דוקטורט) על חייך ועל חיי משפחתך? \\
\hline 829 & 3.08 & 3 & 3.66 & עד כמה תהליך הקליטה של משפחתך בארץ היה קשה? \\
\hline 945 & & & $71 \%$ & המספר מתקבליצג את המוסד שרצית בעדיפות השיב "כן" הראשונה? \\
\hline 946 & 3.02 & 7 & 6.54 & עד כמה תמכו בך חוקרים ותיקים במחלקה ובפקולטה מבחינה מקצועית? \\
\hline 957 & & & $58 \%$ & המספר מייצג את השיעור שהשיר מוסדר/ים באן" באוניברסיטה? \\
\hline 527 & 3.38 & 6 & 5.59 & ואם כן, באיזו מידה הקשר עם המנטור הועיל לך? \\
\hline 884 & 3.06 & 7 & 6.17 & עד כמה תמכו בך חוקרים צעירים אחרים? \\
\hline 921 & 2.93 & 3 & 3.50 & עד כמה קיבלת הנחיה והכנה לתפקידים ניהוליים? \\
\hline 813 & 3.10 & 6 & 5.55 & האם יש בהנחייתך מספיק סטודנטים בכדיי לבצע את המחקר שלך? \\
\hline \multirow[t]{9}{*}{897} & 2.69 & 7 & 5.98 & עד כמה קיבלת הנחיה ועזרה בפנייה לקרנות מחקר ובהגשת בקשות למענקים? \\
\hline & & & & למענקים? גורם/ים קיבלת הנים הגורמים ועזרה ברלוונטיים לייה לקרנות מחקר ובהגשת בקשות \\
\hline & & & 222 & מנטור \\
\hline & & & 103 & 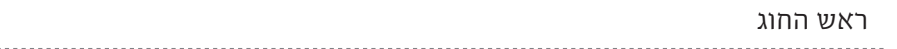 \\
\hline & & & 58 & 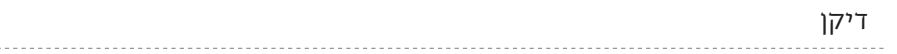 \\
\hline & & & 705 & 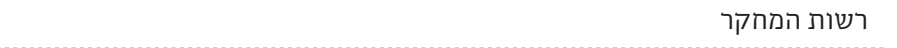 \\
\hline & & & 50 & חברת ייעוץ פרטית \\
\hline & & & 329 & קולגות מאוניברסיטאות אחרות \\
\hline & & & 42 & אחר \\
\hline
\end{tabular}




\begin{tabular}{|c|c|c|c|c|}
\hline מס' משיבים & סטיית תקן & 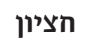 & 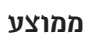 & \\
\hline 905 & 3.09 & 4 & 4.40 & בקיזורים להורה קיבלת עזרה מהמערכת האדמיניסטרטיבית במחלקה שלך בנושאים \\
\hline 890 & 3.32 & 3 & 3.89 & בקשורים למחקר קיבלת עזרה מהמערכת האות מחקר? \\
\hline 880 & 2.96 & 4 & 4.40 & 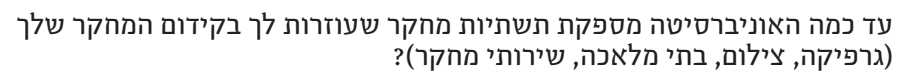 \\
\hline 924 & 2.12 & 7 & 7.14 & בפקולטה)? כבוהה לדעתך רמת סביבת המחקר שלך (החוקרים האחרים במחלקה או \\
\hline 940 & & & $97 \%$ & האם קיבלת משרד? המספר מייצג את השיעור שהשיב "כן" \\
\hline 898 & 2.54 & 9 & 7.90 & עד כמה תאם המשרד שקיבלת את צרכיך? \\
\hline 866 & & & $69 \%$ & 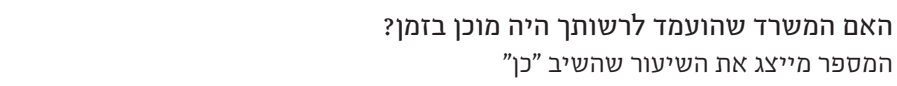 \\
\hline 269 & 2.61 & 4 & 3.83 & אם לא, עד כמה נפגעה עבודת המחקר בעקבות כך? \\
\hline 384 & 2.42 & 8 & 7.20 & עד כמה תאמה המעבדה שקיבלת את צרכיך? \\
\hline 366 & & & $34 \%$ & 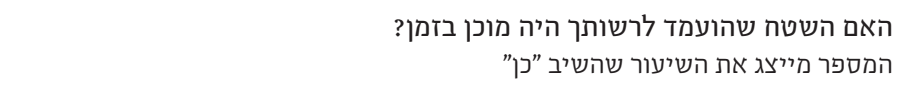 \\
\hline 236 & 2.67 & 7 & 6.19 & אם לא, עד כמה נפגעה עבודת המחקר בעקבות כך? \\
\hline 844 & 2.50 & 8 & 7.35 & את צאיזו מידה הספריות או מאגרי המידע במוסד שבו את/ה מלמד/ת מספקים \\
\hline 876 & 2.01 & 9 & 8.07 & האם האוניברסיטה מאפשרת גישה מספקת למאגרי מידע ולתכנים מקוונים? \\
\hline 872 & 3.00 & 5 & 5.20 & הפקולטות שאוניבריטה מקומנת ומתומודדת שיתוף פעולה בין חוקרים צעירים \\
\hline 869 & 2.75 & 8 & 7.07 & עד כמה מכסת ההוראה משפיעה על יכולתך לחקור? \\
\hline 865 & 2.79 & 6 & 5.92 & לחק כמה כמות העבודה הלא מדעית (כמו כהונה בוועדות וכד) משפיעה על יכולתך \\
\hline 852 & 3.52 & 7 & 5.95 & עד כמה קיבלת הקלות במכסת ההוראה בשנה הראשונה להגעתך? \\
\hline 904 & & & $84 \%$ & האם קיבלת כספי קליטה? המספר מייצג את השיעור שהשיב "כן" \\
\hline 752 & 2.96 & 7 & 6.56 & האם כספי קליטה אלו מספקים? \\
\hline 682 & 2.97 & 7 & 6.85 & במודתך המחקרית? הקליטה לא היו מספקים, עד כמה נפגעה יכולתך לקדם את \\
\hline 894 & & & $52 \%$ & המספר מיבלת מימון מלגות לדוקטורנטים מהשיב שהוניברסיטה? \\
\hline 432 & 2.73 & 7 & 6.53 & במידה וכן, עד כמה מספק היה מימון זה בקידום עבודתך המחקרית? \\
\hline 332 & 3.42 & 5 & 4.90 & במידה ולא, עד כמה נפגעה יכולתך לקדם את עבודתך המחקרית? \\
\hline 883 & & & $78 \%$ & האם קיבלת מימון מלגות לבתר־דוקטורט מהאוניברסיטה? \\
\hline 174 & 2.58 & 7 & 6.87 & במידה וכן, עד כמה מספק היה מימון זה בקידום עבודתך המחקרית? \\
\hline 543 & 3.49 & 5 & 4.50 & במידה ולא, עד כמה נפגעה יכולתך לקדם את עבודתך המחקרית? \\
\hline
\end{tabular}




\begin{tabular}{|c|c|c|c|c|}
\hline 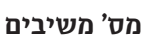 & 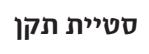 & 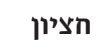 & 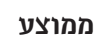 & \\
\hline 889 & 2.97 & 0 & 1.87 & האם היו נסיעות מקצועיות חשובות אשר נמנעת מהן בשל היעדר תקציב? \\
\hline 804 & 3.20 & 7 & 6.52 & האם הצלחת לקבל מספיק מענקי קרנות מחקר למימון מלגות ומשכורות? \\
\hline 807 & 3.23 & 6 & 5.73 & עד כמה תמכה בך האוניברסיטה ברכישת ציוד וחומרים? \\
\hline 869 & 3.49 & 5 & 4.86 & מחקם קיות? \\
\hline 863 & 2.45 & 7 & 6.90 & שלך באוניבר האקיטאות אחרותות במחקרית של הסטודנטים בחוג שלך ביחס לדיסציפלינה \\
\hline 182 & 4.10 & 5 & 4.46 & במידה ולקחת חופשת לידה, האם קיבלת הארכת זמן בתהליך הקידום עקב כך? \\
\hline 418 & 3.34 & 8 & 6.98 & האם הליך קבלת הקביעות או הקידום היה ענייני ועל בסיס מקצועי בלבד? \\
\hline 345 & 3.39 & 5 & 4.70 & במידה ועברת, האם ההליך היה מהיר ויעיל? \\
\hline 358 & 3.25 & 3 & 3.74 & במידה ועברת, האם ההליך התאפיין בשקיפות? \\
\hline \multirow[t]{11}{*}{357} & 3.36 & 5 & 4.62 & במידה ועברת, האם ההליך התאפיין בבהירות הדרישות והקריטריונים? \\
\hline & & & & האם הינך שייך/ת לקבוצ/ות מיעוט \\
\hline & & & 588 & לא שייך/ת לקבוצת מיעוט \\
\hline & & & 96 & מגדר \\
\hline & & & 31 & אוריינטציה־מינית \\
\hline & & & 14 & דת \\
\hline & & & 12 & 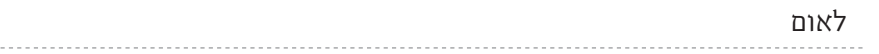 \\
\hline & & & 25 & עדה \\
\hline & & & 9 & גיל \\
\hline & & & 9 & מוגבלות \\
\hline & & & 33 & אחר \\
\hline & 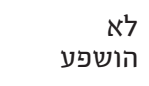 & לרעה הושפע & 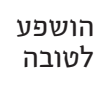 & 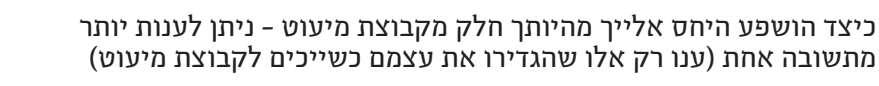 \\
\hline & 50 & 33 & 12 & מגדר \\
\hline & 28 & 3 & 0 & אוריינטציה־מינית \\
\hline & 9 & 2 & 4 & דת \\
\hline & 5 & 4 & 3 & לאום \\
\hline & 18 & 6 & 2 & עדה \\
\hline & 4 & 6 & 0 & גיל \\
\hline & 5 & 0 & 3 & מוגבלות \\
\hline
\end{tabular}

\begin{tabular}{|c|c|c|}
\hline לא & 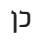 & \\
\hline 298 & 17 & האם חווית הטרדה מינית באוניברסיטה (נשים)? \\
\hline 528 & 5 & האם חווית הטרדה מינית באוניברסיטה (גברים)? \\
\hline
\end{tabular}




\section{Z}

\section{מאפיינים דמוגרפיים}

מס' משיבים

162

125

152

182

136

26

114

66

0

מוסד אקדמי

אוניברסיטת בן־גוריון בנגב

אוניברסיטת בר־אילן אוניברסיטת חיפה אוניברסיטת תל אביב האוניברסיטה העברית ירושליים האוניברסיטה הפתוחה הטכניון - מכון טכנולוגי לישראל מכון ויצמן למדע

אוניברסיטת אריאל בשומרון"

פקולטה

מדעי הרוח מדעי החברה מדעים מדויקים מדעי החיים 97 הנדסה 26 משפטים שילוב של כמה פקולטות 


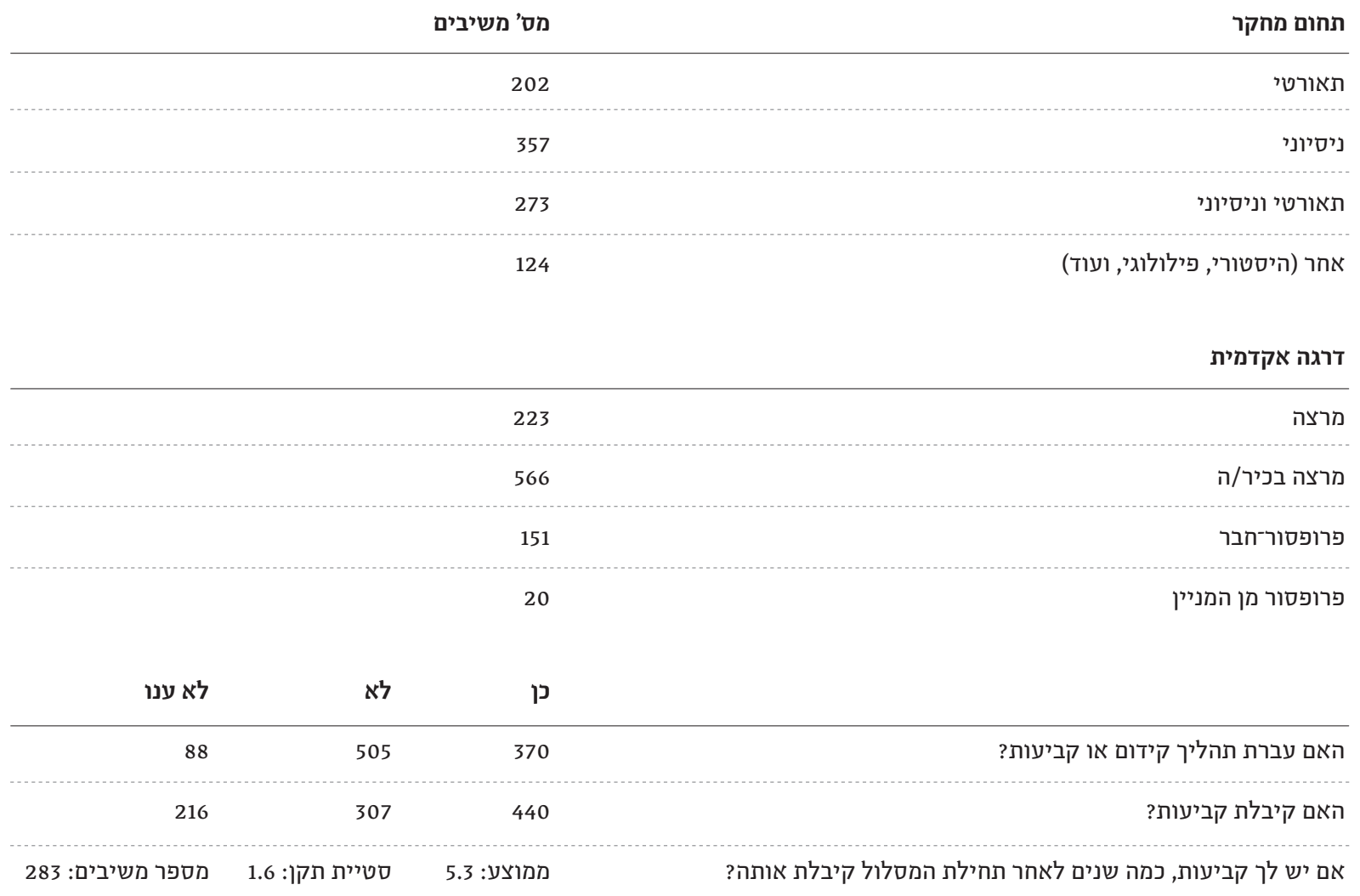

\begin{tabular}{|c|c|c|c|c|c|c|}
\hline לא עשיתי & אוסטרליה & אמריקה & אסיה & אירופה & ישראל & \\
\hline- & 2 & 122 & 0 & 30 & 726 & היכן עשית דוקטורט? \\
\hline 84 & 5 & 537 & 0 & 144 & 110 & היכן עשית בתר־דוקטורט? \\
\hline
\end{tabular}

\begin{tabular}{|c|c|c|}
\hline זרים - ממוצע & ישראלים - ממוצע & \\
\hline 0.25 & 3.8 & כמה מסטרנטים בהנחייתך? \\
\hline 0.38 & 2.8 & כמה דוקטורנטים בהנחייתך? \\
\hline 1.03 & 0.98 & כמה בתר־דוקטורנטים בהנחייו \\
\hline
\end{tabular}

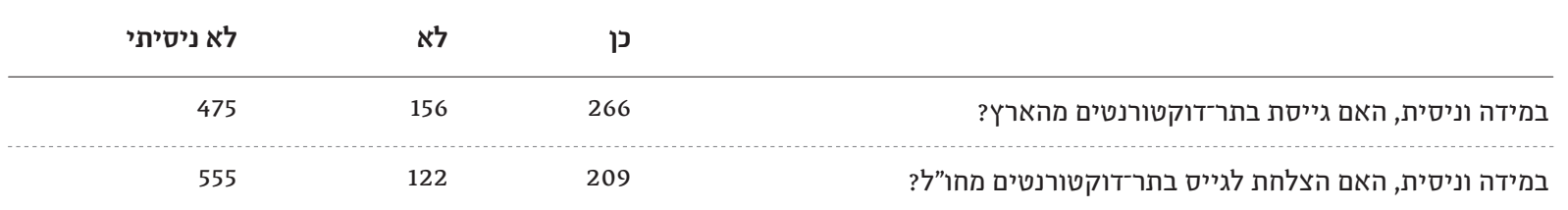




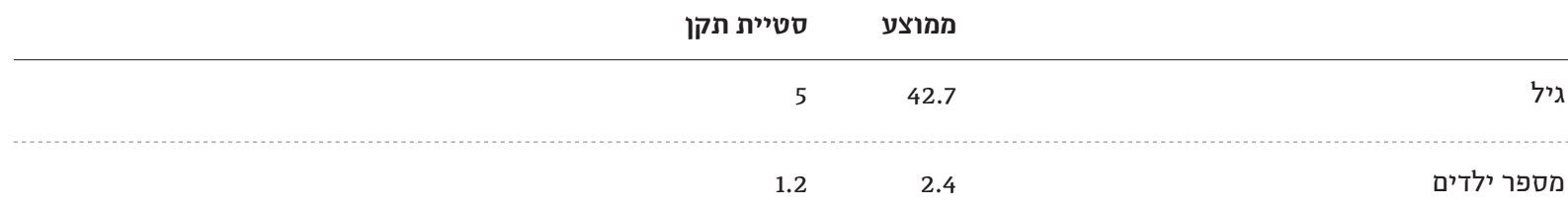

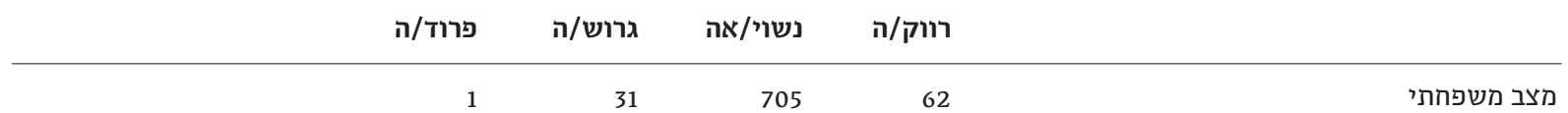

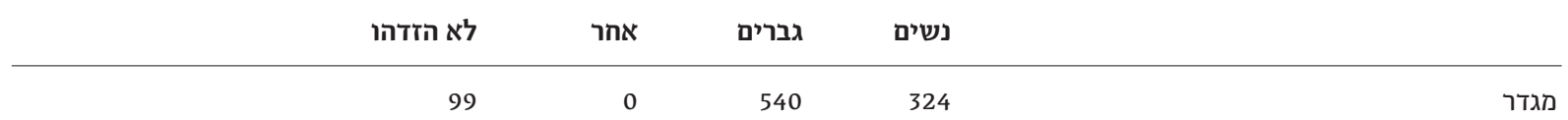

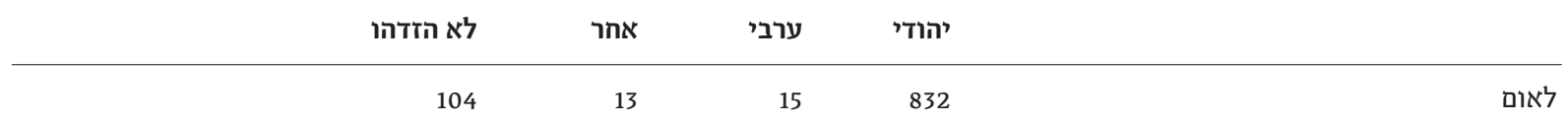

\begin{tabular}{|c|c|c|c|c|c|c|}
\hline לא הזדהו & אחר & אתיופי & מעורב & אשכנזי & מזרחי & \\
\hline 66 & 0 & 0 & 129 & 557 & 80 & מוצא/עדה (השיבו יהודים בלבד) \\
\hline
\end{tabular}




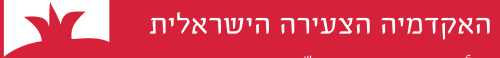

الأكاديمية الثـابّة الإسرائيلية

THE ISRAEL YOUNG ACADEMY

דוא"ל: IsraelYoungAcademy@academy.ac.il

www.young.academy.ac.il 